\title{
Fischer-Tropsch synthesis: Effect of ammonia on supported cobalt catalysts
}

Venkat Ramana Rao Pendyala ${ }^{1}$, Gary Jacobs ${ }^{1}$, Clement Bertaux ${ }^{1}$, Syed Khalid ${ }^{2}$, Burtron H. Davis ${ }^{1 *}$

${ }^{1}$ Center for Applied Energy Research, University of Kentucky, 2540 Research Park Drive, Lexington, KY-40511, USA

${ }^{2}$ NSLS, Brookhaven National Laboratories, Brookhaven Ave., Upton, NY-11973, USA

\begin{abstract}
The effect of ammonia in syngas on the performance of various supported cobalt catalysts (i.e., $\mathrm{Al}_{2} \mathrm{O}_{3}, \mathrm{TiO}_{2}$ and $\mathrm{SiO}_{2}$ ) was investigated during Fischer-Tropsch synthesis (FTS) using a continuously stirred tank reactor (CSTR). The addition of ammonia (10 ppmv $\mathrm{NH}_{3}$ ) caused a significant deactivation for all supported cobalt catalysts, but the rate of deactivation was higher for the silica-supported catalysts relative to the alumina and titania-supported catalysts used in this work. Ammonia addition had a positive effect on product selectivity (i.e., lower light gas products and higher $\mathrm{C}_{5}+$ ) for alumina and titania-supported catalysts compared to ammonia free conditions, whereas, the addition of ammonia increased lighter hydrocarbon $\left(\mathrm{C}_{1^{-}}\right.$ $\left.\mathrm{C}_{4}\right)$ products and decreased higher hydrocarbon $\left(\mathrm{C}_{5}+\right)$ selectivity compared to ammonia-free synthesis conditions for the silica-supported catalyst. For alumina and titania-supported catalysts, the activity almost recovered with mild in-situ hydrogen treatment of the ammonia exposed catalysts. For the silica-supported catalyst, the loss of activity is somewhat irreversible (i.e., cannot be regained after the mild hydrogen treatment). Addition of ammonia led to a significant loss in BET surface area and changes in pore diameter (consistent with pore collapse of a fraction of pores into the microporous range as described in the literature), as well as formation of catalytically inactive cobalt support compounds for the silica-supported catalyst. On the other hand, the pore characteristics of alumina and titania-supported catalysts were not significantly
\end{abstract}


changed. XANES results of the ammonia exposed silica-supported catalysts further confirm the formation of cobalt-support compounds (cobalt silicates).

Keywords: Fischer-Tropsch synthesis; effect of ammonia; supported cobalt catalysts; EXAFS/XANES; deactivation; product selectivity.

*Corresponding author. Tel.: +1 859257 0251; Fax: +1 8592570302.

E-mail: burtron.davis@,uky.edu (B.H. Davis)

\section{Introduction}

Fischer-Tropsch synthesis (FTS) is a key industrial process to catalytically convert syngas (a mixture of $\mathrm{CO}$ and $\mathrm{H}_{2}$ ) to liquid hydrocarbons and chemicals via a surface polymerization reaction $[1,2]$. In comparison to traditional petroleum-derived liquid hydrocarbons, the FTS liquid hydrocarbons are free of sulfur and aromatic pollutants [3-5], which make them ideal candidates for the synthesis of clean transportation fuels. Syngas can be produced from various carbonaceous sources [6-8], such as natural gas, coal, biomass, shale gas, through steam reforming, partial or auto-thermal oxidation, or gasification processes. Therefore, the FTS process is of prominent interest to both academia and industry. The Fischer-Tropsch (FT) reaction was shown to be catalyzed by certain transition metals including $\mathrm{Ru}, \mathrm{Fe}$, and $\mathrm{Co}$ [1]. Ru-based catalysts are highly active, but the Ru resource is scarce and expensive; thus, it is not used commercially [4]. Co-based FTS catalysts are usually preferred for certain applications (e.g., GTL) because these catalysts are more active per weight of metal, more stable toward deactivation by water (a by-product of the FTS reaction), have lower activity for the competing water-gas-shift (WGS) reaction, and produce a higher fraction of linear long-chain paraffins and less oxygenates than Fe-based catalysts [9-12].

Gasification and reforming are processes in which a carbon source (biomass, coal, petcoke or natural gas) is converted to synthesis gas in the presence of oxygen and/or steam. This 
synthesis gas (or syngas) can then be converted to transportation fuels via Fischer-Tropsch synthesis. Biomass-derived synthesis gas can contain both organic and inorganic impurities such as tars, benzene, toluene, xylene, $\mathrm{NH}_{3}, \mathrm{HCN}, \mathrm{H}_{2} \mathrm{~S}, \mathrm{COS}, \mathrm{HCl}$, volatile metals, dust, and soot [13]. Coal, which originates from biomass, typically contains all of the same inorganic impurities as found in biomass [14]. Hence, technologies for the removal of these impurities have already been developed in connection with large-scale CTL plants. However, these plants normally operate with iron catalysts while most BTL concepts to date are based on cobalt catalysts. Iron and cobalt catalysts share the sensitivity toward some, but not all, of the impurities commonly found in coal and biomass-derived synthesis gas.

The effect of sulfur was investigated in an earlier study [15]. Very low levels of sulfur $(<250 \mathrm{ppbv})$ may increase the CO conversion and sulfur levels up to $438 \mathrm{ppbv}$ did not exhibit a poisoning effect. On the other hand, irreversible deactivation was observed at higher concentrations ( $>500 \mathrm{ppbv})$. Similar findings were observed by Pansare and Alison [16]; they did not observe any detectable deactivation if the synthesis gas contained 50 ppbv $\mathrm{H}_{2} \mathrm{~S}$, while higher concentrations ( $\geq 300$ ppbv) caused significant and irreversible deactivation. Only few studies have reported the effect of ammonia on cobalt and iron-based FT catalysts in the open literature. In a recent investigation [17], we reported the effect of ammonia over a typical Febased catalyst; the Fe catalyst was quite resistant to high levels of ammonia, regardless of whether ammonia gas or ammonium hydroxide was used. Up to $200 \mathrm{ppmw}, \mathrm{NH}_{3}$ was not found to either significantly deactivate the Fe catalyst or measurably change the Fe catalyst selectivity. To date, the effect of ammonia over cobalt catalysts has been less clear; some researchers have reported no effect $[18,19]$, while others have reported an immediate impact on catalytic activity [20-24]. Claeys et al. [18] reported that co-feeding of up to $25 \% \mathrm{NH}_{3}$ in the synthesis gas did not 
affect FT activity, and similar findings were observed by Borg et al. [19] with 4.2 ppmv of ammonia. Poisoning studies of cobalt-based FTS catalysts by means of nitrogen-containing compounds like $\mathrm{NH}_{3}$ and $\mathrm{HCN}$ has been previously published [20-22]. In one study, cobalt catalysts rapidly but reversibly deactivated by $\mathrm{HCN}$ and $\mathrm{NH}_{3}$ [20]. Syntroleum workers showed that cobalt catalysts can be deactivated by as much as $16-38 \%$, depending on the type and level of N-containing poison [22]. An Exxon patent [25] claims that a combined concentration of 100 ppb of $\mathrm{NH}_{3}$ and $\mathrm{HCN}$ in synthesis gas will result in a catalyst half-life of only 4 days for supported cobalt catalysts in a slurry reactor. However, the patent also teaches that the catalyst can be rejuvenated by hydrogen treatment to restore the initial activity.

In our previous investigation [23], we reported the effect of ammonia over a Pt-promoted $\mathrm{Co} /$ alumina catalyst by varying the ammonia $\left(\mathrm{NH}_{4} \mathrm{OH}\right)$ concentration from 1 to 1200 ppmw, and the percentage of drop relative to initial conversion was virtually identical at all of the ammonia concentrations (1-1200 ppmw) explored. The effect of ammonia for a Pt-Co/alumina catalyst had a negative effect on $\mathrm{CO}$ conversion and a positive effect on selectivity (i.e., lower methane and higher $\mathrm{C}_{5}+$ ), whereas, the $\mathrm{Co} / \mathrm{SiO}_{2}$ and $\mathrm{Pt}-\mathrm{Co} / \mathrm{SiO}_{2}$ catalysts showed negative effects on both $\mathrm{CO}$ conversion and product selectivity [24]. The aim of the present study is to investigate the effect of ammonia (10 ppmv $\left.\mathrm{NH}_{3}\right)$ on various supported (alumina, silica and titania) cobalt catalysts. All the supported cobalt catalysts exhibited a negative effect on $\mathrm{CO}$ conversion but there is a positive effect on product selectivity for alumina and titania supported catalysts. To investigate the reason for the negative effect on product selectivity for the silica supported catalysts, the catalysts were withdrawn from the reactor prior to and following exposure to ammonia during the FTS reaction, and the samples were investigated using standard $\mathrm{H}_{2}$ TPR and EXAFS and 
XANES spectroscopic techniques. Particular attention was also paid to the capability of each catalyst to recover its activity following a period of exposure to ammonia.

\section{Experimental}

\subsection{Catalyst preparation}

Sasol-Catalox alumina (high purity $\gamma$-alumina, $140 \mathrm{~m}^{2} / \mathrm{g}$ ) was used as the support for the cobalt catalyst. The catalyst was prepared by a slurry impregnation method, and cobalt nitrate was the precursor. In this method, which follows a Sasol patent [26], the ratio of the volume of solution used to the weight of alumina was $1: 1$, such that the volume of solution was approximately 2.5 times the pore volume of the catalyst. Two impregnation steps were used, each to load $12.5 \%$ of Co by weight. After the second impregnation/drying step, the catalyst was calcined under air flow at $350{ }^{\circ} \mathrm{C}$. The promoter was added by incipient wetness impregnation (IWI), and the precursor utilized for noble metal addition was tetraammineplatinum (II) nitrate. After Pt addition, the sample was dried and calcined again at the same conditions as used previously.

PQ silica CS-2133 was also used as a support for cobalt FTS catalysts. An aqueous incipient wetness impregnation (IWI) method was used to load cobalt nitrate (cobalt nitrate hexahydrate, $\mathrm{Co}\left(\mathrm{NO}_{3}\right)_{2} \cdot 6 \mathrm{H}_{2} \mathrm{O}$, Sigma Aldrich, $\left.99.95 \%\right)$ to the support. To obtain a cobalt loading of $20 \mathrm{wt} . \%$, multiple impregnation steps were applied, due to the limited solubility of the cobalt nitrate salt. Following cobalt addition, the resulting slurry was dried at $80-100{ }^{\circ} \mathrm{C}$ in a rotary evaporator following each impregnation step. The solid obtained was dried at $120{ }^{\circ} \mathrm{C}$ overnight and calcined at $350^{\circ} \mathrm{C}$ under flowing air for $4 \mathrm{~h}$.

$0.2 \% \mathrm{Pt}-10 \% \mathrm{Co} / \mathrm{TiO}_{2}$ catalyst was prepared by a single step slurry impregnation method using Degussa P-25 $\mathrm{TiO}_{2}\left(72 \%\right.$ anatase, $50 \mathrm{~m}^{2} / \mathrm{g}$, calcined at $350{ }^{\circ} \mathrm{C}$ for $\left.4 \mathrm{~h}\right)$ with cobalt nitrate 
hexahydrate solution. The sample was dried at $120{ }^{\circ} \mathrm{C}$ for $16 \mathrm{~h}$ and calcined under air flow at 350 ${ }^{\circ} \mathrm{C}$ for $4 \mathrm{~h}$. The promoter was added by incipient wetness impregnation (IWI), and the precursor utilized for noble metal addition was tetraammineplatinum (II) nitrate. After Pt addition, the sample was dried and calcined again at the same conditions as used previously.

Due to the lower surface area $\left(50 \mathrm{~m}^{2} / \mathrm{g}\right)$ of titania support, a loading of $10 \%$ of Co is used in order to obtain smaller Co clusters, whereas alumina and silica supports have higher surface areas 140 and $327 \mathrm{~m}^{2} / \mathrm{g}$, respectively. Due to the higher surface areas of alumina and silica supports, higher cobalt loadings were used. A loading of $0.5 \% \mathrm{Pt}$ is typical of $25 \% \mathrm{Co} / \mathrm{Al}_{2} \mathrm{O}_{3}$ research catalysts for facilitating the reduction of cobalt oxides strongly interacting with the support $[27,28]$. Due to the lower surface area of titania, a loading of $10 \%$ of Co was used in order to obtain Co clusters of similar size [27]. However, since excessive Pt is known promote excessive chain termination [29], a similar Pt/Co ratio was used to facilitate the strongly interacting cobalt oxides with titania. Thus, the weight percentage was decreased to $0.2 \% \mathrm{Pt}$ for the case of $10 \% \mathrm{Co} / \mathrm{TiO}_{2}$. Standard silica supported cobalt catalysts that are air calcined exhibit a weak interaction between cobalt oxides and silica $[27,28]$. No Pt is usually necessary to promote cobalt oxide reduction; therefore, it was not added to the $\mathrm{Co} /$ silica catalysts in the current contribution.

\subsection{Catalyst characterization}

To characterize the ammonia-exposed catalysts, the end-of-run catalyst along with wax was transferred to an air-free environment (inert chamber); moreover, the typical Soxhlet extraction procedure was avoided. Instead, the catalyst sample was diluted with hot ortho-xylene to remove the high molecular weight FT-wax fractions. It was not possible to completely remove the FT-wax from the catalyst particles by this method. However, the remaining wax acts as a 
protective barrier for the air-sensitive catalyst particles. Extracted catalyst was treated mildly with $1 \% \mathrm{O}_{2} / \mathrm{N}_{2}$ at $300{ }^{\circ} \mathrm{C}$ for $4 \mathrm{~h}$ to remove the wax product formed from FTS, prior to characterization of temperature programmed reduction (TPR) measurements. In a very recent study, Keyvanloo et al. [30] also followed similar procedure for the wax extraction.

\subsubsection{BET surface area and porosity measurements}

BET surface area and porosity measurements of the calcined and ammonia pre-treated alumina, titania and silica supported-cobalt catalysts were conducted using a Micromeritics 3Flex unit. Before performing the test, the temperature was gradually ramped to $160{ }^{\circ} \mathrm{C}$ and the sample was evacuated for at least $12 \mathrm{~h}$ to approximately $50 \mathrm{mTorr}$. BET surface area, pore volume, and average pore radius were obtained for each sample.

\subsubsection{Temperature programmed reduction (TPR)}

Temperature programmed reduction (TPR) profiles of calcined and used catalysts were recorded using a Zeton-Altamira AMI-200 unit equipped with a thermal conductivity detector (TCD). Samples were pretreated by purging with flowing argon at $350{ }^{\circ} \mathrm{C}$ to remove traces of water. The TPR was performed using a $10 \% \mathrm{H}_{2} / \mathrm{Ar}$ gas mixture and referenced to argon at a flow rate of $30 \mathrm{~cm}^{3} / \mathrm{min}$. Calcined, ammonia pre-treated and used catalyst samples were heated from 50 to $1000{ }^{\circ} \mathrm{C}$ at a heating ramp of $10{ }^{\circ} \mathrm{C} / \mathrm{min}$.

\subsubsection{Hydrogen chemisorption and pulse reoxidation}

Hydrogen chemisorption was conducted using temperature programmed desorption (TPD), also measured with the Zeton Altamira AMI-200 instrument. The sample weight was typically $\sim 0.22 \mathrm{~g}$. Catalysts were activated in a flow of $10 \mathrm{~cm}^{3} / \mathrm{min}$ of $\mathrm{H}_{2}$ mixed with $20 \mathrm{~cm}^{3} / \mathrm{min}$ of argon at $350{ }^{\circ} \mathrm{C}$ for $12 \mathrm{~h}$, and then cooled under flowing $\mathrm{H}_{2}$ to $100{ }^{\circ} \mathrm{C}$. The sample was held at $100{ }^{\circ} \mathrm{C}$ under flowing argon to remove and/or prevent adsorption of weakly bound species prior 
to increasing the temperature slowly to $350{ }^{\circ} \mathrm{C}$, the reduction temperature of the catalyst. The catalyst was held under flowing argon to desorb remaining chemisorbed hydrogen until the TCD signal returned to baseline. The TPD spectrum was integrated and the number of moles of desorbed hydrogen determined by comparing its area to the areas of calibrated hydrogen pulses. The loop volume was first determined by establishing a calibration curve with syringe injections of hydrogen in helium flow. Dispersion calculations were based on the assumption of a 1:1 H:Co stoichiometric ratio and a spherical cobalt cluster morphology. After TPD of hydrogen, the sample was reoxidized at $350{ }^{\circ} \mathrm{C}$ using pulses of oxygen. The percentage of reduction was calculated by assuming that the metal reoxidized to $\mathrm{Co}_{3} \mathrm{O}_{4}$. Further details of the procedures are provided elsewhere [27].

\subsubsection{XANES/EXAFS spectroscopy}

For XANES/EXAFS analysis, two catalyst slurry samples were collected in inert environment during the experiment involving alumina, titania and silica supported cobalt catalysts; one was collected before and the other sample was collected after the addition of ammonia (during the FTS run). The collected slurry samples were moved into the oxygen free chamber and fixed in sample holders, without removing the wax. A wax removal procedure was avoided so that the catalyst particles would not be exposed to air.

The samples were uniform in composition and pinhole free. EXAFS/XANES spectra were recorded in transmission mode at the Stanford Synchrotron Radiation Light source (SSRL) at the Stanford Linear Accelerator (SLAC) Stanford University, Palo Alto, California, Beamline 2-2. The beamline is equipped with a $\mathrm{Si}$ (111) and a $\mathrm{Si}(220)$ monochromator. A crystal detuning procedure was used to help remove harmonic content from the beam and make the relative response of the incident and transmission detectors more linear. The x-ray flux for the beamline 
was on the order of $1 \mathrm{E} 11$ photons per second at $500 \mathrm{~mA}$ and $3.0 \mathrm{GeV}$ at $11 \mathrm{keV}$ with $\mathrm{Si}$ (111) monochromator, and the usable energy range at 2-2 is from 3.5 to $37 \mathrm{keV}$. XANES spectra were recorded at room temperature. A sample thickness was determined by calculating the amount in grams per square centimeter of sample, $w_{D}$, by utilizing the thickness equation:

$$
\mathrm{W}_{\mathrm{D}}=\ln \left(\mathrm{I}_{0} / \mathrm{I}_{\mathrm{t}}\right) / \Sigma\left\{(\mathrm{m} / \mathrm{r})_{\mathrm{j}} \mathrm{w}_{\mathrm{j}}\right\}
$$

where $\mathrm{m} / \mathrm{r}$ is the total cross section (absorption coefficient/density) of element $\mathrm{j}$ in the sample at the absorption edge of the XANES element under study in $\mathrm{cm}^{2} / \mathrm{g}, \mathrm{w}_{\mathrm{j}}$ is the weight fraction of element $\mathrm{j}$ in the sample, and $\ln \left(\mathrm{I}_{0} / \mathrm{I}_{\mathrm{t}}\right)$ was taken over a typical range of 1 to 2.5 . An average value of $\mathrm{w}_{\mathrm{D}}$ from inputting both values was employed. Based on the calculation for $\mathrm{w}_{\mathrm{D}}$, and the crosssectional area of the pellet, the weight was calculated. XANES data reduction and fitting were carried out using the WinXAS program [31]. XANES spectra were compared qualitatively after normalization.

\subsection{Catalytic activity testing}

The FTS experiments were conducted using a 1 L CSTR equipped with a magnetically driven stirrer with turbine impeller, a gas-inlet line, and a vapor outlet line with a stainless steel (SS) fritted filter $(2 \mu \mathrm{m})$ placed external to the reactor. A tube fitted with a SS fritted filter $(0.5$ $\mu \mathrm{m}$ opening) extending below the liquid level of the reactor was used to withdraw reactor wax (i.e., rewax, which is solid at room temperature), thereby maintaining a relatively constant liquid level in the reactor. Separate mass flow controllers were used to control the flow rates of hydrogen and carbon monoxide. Carbon monoxide, prior to use, was passed through a vessel containing lead oxide on alumina to remove traces of iron carbonyls. The gases were premixed in an equalization vessel and fed to the CSTR below the stirrer, which was operated at $750 \mathrm{rpm}$. The reactor temperature was maintained constant $\left( \pm 1^{\circ} \mathrm{C}\right)$ using a temperature controller. 
The catalyst ( $12.0 \mathrm{~g})$ was ground and sieved to $45-100 \mu \mathrm{m}$ before loading into a fixedbed reactor for $12 \mathrm{~h}$ of ex-situ reduction at $350{ }^{\circ} \mathrm{C}$ and atmospheric pressure using a gas mixture of $\mathrm{H}_{2} / \mathrm{He}(60 \mathrm{NL} / \mathrm{h})$ with a molar ratio of $1: 3$. The reduced catalyst $(\sim 10.0 \mathrm{~g})$ was transferred to a 1-L continuously stirred tank reactor (CSTR) containing $310 \mathrm{~g}$ of melted Polywax 3000, under the protection of inert nitrogen gas. The transferred catalyst was further reduced in-situ at $230{ }^{\circ} \mathrm{C}$ at atmospheric pressure using pure hydrogen $(20 \mathrm{NL} / \mathrm{h})$ for another $24 \mathrm{~h}$ before starting the FT reaction. In this study, the FTS conditions used were $220{ }^{\circ} \mathrm{C}, 1.9 \mathrm{MPa}, \mathrm{H}_{2} / \mathrm{CO}=2$, and a stirrer speed of $750 \mathrm{rpm}$.

Gas, water, oil, light wax, and heavy wax samples were collected daily and analyzed. Heavy wax samples were collected in a $200{ }^{\circ} \mathrm{C}$ hot trap connected to the filter. The vapor phase in the region above the reactor slurry passed continuously to the warm $\left(100^{\circ} \mathrm{C}\right)$ and then the cold $\left(0^{\circ} \mathrm{C}\right)$ traps located external to the reactor. The light wax and water mixture were collected daily from the warm trap and an oil plus water sample from the cold trap. Tail-gas from the cold trap was analyzed with an online HP Quad Series Micro GC, providing molar compositions of $\mathrm{C}_{1}-\mathrm{C}_{7}$ olefins and paraffins, as well as $\mathrm{H}_{2}, \mathrm{CO}$ and $\mathrm{CO}_{2}$. Hydrogen and carbon monoxide conversions were calculated based on GC analysis of the gas products, the gas feed rate, and the gas flow that was measured at the outlet of the reactor.

\section{Results and discussion}

The results of BET surface area and pore size characteristics are shown in Table 1. $\gamma$ $\mathrm{Al}_{2} \mathrm{O}_{3}$ (Sasol Catalox, Sba-150) was used as a support and its specific BET surface is $140 \mathrm{~m}^{2} / \mathrm{g}$. The analyses were performed for calcined catalysts, and $\mathrm{Co}_{3} \mathrm{O}_{4}$ was deemed to be the major cobalt compound in the calcined catalyst [27]. $33 \% \mathrm{Co}_{3} \mathrm{O}_{4}$ by weight was calculated by assuming $25 \mathrm{wt} \%$ Co metals in the $\mathrm{Co} / \mathrm{Al}_{2} \mathrm{O}_{3}$ catalyst were completely converted to $\mathrm{Co}_{3} \mathrm{O}_{4}$ after 
calcination. Thus, if $\mathrm{Al}_{2} \mathrm{O}_{3}$ is the only contributor to the area, then the area of $25 \% \mathrm{Co} / \mathrm{Al}_{2} \mathrm{O}_{3}$ catalysts should be $140 \times 0.67=93.8 \mathrm{~m}^{2} / \mathrm{g}$, which is very close to the measured value of $96 \mathrm{~m}^{2} / \mathrm{g}$. For the Degussa $\mathrm{P}-25 \mathrm{TiO}_{2}$ supported cobalt catalyst, the area of $10 \% \mathrm{Co} / \mathrm{TiO}_{2}$ catalyst should be $50 \times 0.864=43.2 \mathrm{~m}^{2} / \mathrm{g}$, and the area was $42 \mathrm{~m}^{2} / \mathrm{g}$, very close to the measured value. In the case of the PQ $\mathrm{SiO}_{2}$ supported cobalt catalysts, the anticipated area was $0.73 \times 327=238.7 \mathrm{~m}^{2} / \mathrm{g}$, which is close to the measured value of $236 \mathrm{~m}^{2} / \mathrm{g}$; thus, the results for these catalysts indicate that no significant pore blockage occurred.

Hydrogen chemisorption and pulse reoxidation results of alumina, titania and silica supported cobalt catalysts are presented in Table 2. Chemisorption results indicate that the reduction degree of $\mathrm{Pt}$ promoted Co supported on the $\gamma-\mathrm{Al}_{2} \mathrm{O}_{3}$ was $60 \%$, and average Co diameter was found to be $10.8 \mathrm{~nm}$. The reduction degree of Pt promoted Co supported $\mathrm{TiO}_{2}$ catalyst was $76 \%$, and average $\mathrm{CO}$ diameter was found to be $10.3 \mathrm{~nm}$. For the $20 \% \mathrm{Co} / \mathrm{SiO}_{2}$ a relatively similar Co reduction degree $\mathbf{7 1 \% )}$ was obtained but the average Co cluster diameter was significantly larger $(38 \mathrm{~nm})$ compared to those of the alumina and titania supported cobalt catalysts. This indicates that, despite the much higher surface area of the silica support, it was the weaker interaction between the $\mathrm{SiO}_{2}$ support and the Co oxides that led to the formation of larger Co clusters exhibiting reduction behavior that was closer to bulk-like $\mathrm{Co}_{3} \mathrm{O}_{4}$ reduction (i.e., more facile reduction). In our previous work [27], the stronger interaction between the $\mathrm{Al}_{2} \mathrm{O}_{3}$ and $\mathrm{TiO}_{2}$ supports and the Co oxide species led to a higher fraction of the cobalt remaining unreduced after activation (i.e., less facile reduction) but, more importantly, to the stabilization of much smaller Co clusters. By comparing the $\mathrm{H}_{2}$ TPD data [11], which represent a direct correlation with the active site densities, it is evident that the gains in active site densities by the smaller cobalt clusters on $\mathrm{Co} / \mathrm{Al}_{2} \mathrm{O}_{3}$ and $\mathrm{Co} / \mathrm{TiO}_{2}$ catalysts outweighed the losses from the lower extents of 
reduction, in comparison with the $\mathrm{Co} / \mathrm{SiO}_{2}$ catalyst. This should dispel the notion that catalysts with greater ease of reduction should automatically be preferable to those having lower extents of reduction, since one must also carefully consider, perhaps even more so, the resulting average Co cluster size.

The effect of ammonia during FT synthesis over supported (alumina, titania and silica) cobalt catalysts was studied by co-feeding $10 \mathrm{ppmv}$ ammonia gas with the synthesis gas feed. To maintain experimental control, similar activation and reaction conditions (partial pressures of $\mathrm{CO}$ and $\mathrm{H}_{2}$ ) were maintained during all periods. After attaining a steady state $\mathrm{CO}$ conversion, 10 ppmv ammonia gas was introduced to the syngas. Significant changes were observed within three hours of the addition of ammonia (i.e., after three turnovers of the reactants and product mixtures in the reactor). The effect of ammonia on $\mathrm{CO}$ conversion for a $\mathrm{Co} /$ alumina catalyst is shown in Figure 1. The addition of $10 \mathrm{ppmv} \mathrm{NH}_{3}$ led to a significant drop in $\mathrm{CO}$ conversion from $53 \%$ to $39 \%$, but the CO conversion was almost constant with continued addition of ammonia (i.e., following a step decrease in activity). More importantly, CO conversion did not recover to the expected value, even after termination of the ammonia addition under normal FTS conditions, indicating that the catalyst had deactivated irreversibility (i.e., $\mathrm{NH}_{\mathrm{x}}$ species are strongly adsorb to deactivate cobalt active sites). To detect the ammonia, the tail gas stream was monitored using "Kitagawa" tubes, but we did not observe any detectable amount of ammonia in the gas stream. However, we observed a significant amount of ammonia in the aqueous phase, even though the observed amount is lower than the introduced amount into the reactor. These findings indicate that some of the $\mathrm{NH}_{\mathrm{x}}$ species are retained on the catalyst and probably the liquid hydrocarbon fraction. The effect of $10 \mathrm{ppmv}$ ammonia on methane and $\mathrm{C}_{5}+$ selectivities for the Co/alumina catalyst is shown in Figure 2. Prior to the ammonia addition, methane and 
$\mathrm{C}_{5}+$ selectivities were $9.0 \%$ and $79 \%$, respectively. During $10 \mathrm{ppmv} \mathrm{NH}_{3}$ addition, the methane selectivity dropped to $8.4 \%$ and $\mathrm{C}_{5}+$ selectivity increased to $80 \%$ following the decrease in $\mathrm{CO}$ conversion from $53 \%$ to $38.2 \%$. Generally, for the cobalt FT catalysts, with decreasing CO conversion methane selectivity increases and $\mathrm{C}_{5}+$ selectivity decreases [19]. FTS product selectivities should be compared at similar CO conversion levels, because the conversion level influences the selectivity, in part due to varying the partial pressure of water and partial pressure of reactants with conversion levels. But in the present study, the product selectivities were not directly compared at similar conversion levels of various supported catalysts. The selectivity trends of the various supported cobalt catalysts were compared before and after addition of ammonia, because we were primarily interested in the poisoning effect of activity.

Similarly, the effect of ammonia was investigated for the $0.2 \% \mathrm{Pt}-10 \% \mathrm{Co} / \mathrm{TiO}_{2}$ catalyst at similar activation and reaction conditions except the space velocity. After attaining a stable CO conversion, $10 \mathrm{ppmv}$ ammonia gas was added to the syngas stream. The effect of ammonia on CO conversion for Co/titania catalyst is shown in Figure 3. The addition of ammonia led to a significant drop in $\mathrm{CO}$ conversion during the first day and after that, the $\mathrm{CO}$ conversion slightly decreased with further addition of ammonia. A step decrease in catalytic activity was observed similar to that of the Co/alumina catalyst. After termination of ammonia addition from syngas, no significant improvement in $\mathrm{CO}$ conversion was observed. Figure 4 shows the effect of ammonia on product selectivity $\left(\mathrm{C}_{1}\right.$ and $\left.\mathrm{C}_{5}+\right)$ for the $\mathrm{Co} /$ titania catalyst. After the addition of ammonia, methane selectivity decreased slightly and the corresponding $\mathrm{C}_{5}+$ selectivity slightly increased relative to ammonia-free synthesis conditions; in short, it followed similar trends as observed with the Co/alumina catalyst. 
Finally, the effect of ammonia was also studied for the $20 \% \mathrm{Co} / \mathrm{SiO}_{2}$ catalyst under similar conditions. The effect of ammonia on $\mathrm{CO}$ conversion for $\mathrm{Co} /$ silica is shown in Figure 5. The addition of ammonia caused a tremendous decrease in $\mathrm{CO}$ conversion for the first $24 \mathrm{~h}$ on stream and after that, the conversion remained almost constant with further addition of ammonia (i.e., a step decrease in catalytic activity). After the termination of the ammonia addition from syngas, no significant improvement in CO conversion was observed even after $100 \mathrm{~h}$ of ammonia-free synthesis conditions. The effect of ammonia on methane and $\mathrm{C}_{5}+$ selectivities of a $\mathrm{Co} /$ silica catalyst is shown in Figure 6 . The addition of ammonia increased methane selectivity and decreased the $\mathrm{C}_{5}+$ selectivity, whereas for the Co/alumina and Co/titania catalysts, methane selectivity slightly decreased and $\mathrm{C}_{5}+$ selectivity slightly increased after the ammonia exposure, even though the CO conversion was decreased. These results indicate that the silica supported catalyst behaves somewhat differently than the alumina and titania supported-cobalt catalysts with exposure to ammonia. In our earlier study [24], the effect of ammonia over Pt promoted and un-promoted $20 \% \mathrm{Co} / \mathrm{SiO}_{2}$ catalysts was investigated. Similar trends were observed for the unpromoted and Pt-promoted silica supported cobalt catalysts, and the Pt promoted catalyst was more deactivated than the un-promoted catalyst during the ammonia exposure. Regarding the conversion and selectivity trends, Pt promoter does not display any additional benefits relative to the un-promoted silica supported cobalt catalyst.

The relative $\mathrm{CO}$ conversions for the cobalt catalysts at $10 \mathrm{ppm}$ of ammonia relative to the pre-exposure conditions are shown in Figure 7. Ammonia exposure causes similar deactivation rate trends with time for the alumina and titania-supported catalysts, whereas a higher deactivation rate was observed for the silica supported catalyst compared to the others. The Anderson-Schultz-Flory (ASF) model is a common model used to describe the chain growth 
mechanism in FTS and was developed based on Flory's pioneering studies on the fundamental nature of polymerization. Chain growth probability $(\alpha)$ values are reported in Table 3 for the alumina, titania and silica-supported-cobalt catalysts with and without addition of ammonia. For the $\mathrm{Co} /$ alumina catalyst, at baseline conditions (prior to ammonia addition), the $\alpha$ value was 0.85 and after the addition of $10 \mathrm{ppm}$ ammonia it increased to 0.88 ; likewise, for the Co/titania catalyst, at baseline conditions, the $\alpha$ value was 0.88 and after the addition of ammonia it increased to 0.92 . Thus, the addition of ammonia to alumina and titania-supported-cobalt catalysts resulted in a significant increase in the chain growth probability for FTS. For the $\mathrm{Co} / \mathrm{SiO}_{2}$ catalyst, before and after the addition of $10 \mathrm{ppm}$ ammonia addition, the $\alpha$ values did not change significantly.

The ammonia introduction and $\mathrm{CO}$ rates (before and after the addition of ammonia) were compared relative to the cobalt metal area of all catalysts and the results are shown in Table 4 . The silica supported catalyst has a lower metal area than the alumina and titania supported catalysts, due to the larger Co clusters residing on the silica supported catalyst. The effect of ammonia during FT synthesis over supported cobalt catalysts was studied by co-feeding 10 ppmv ammonia gas with the synthesis gas feed. The amount of ammonia introduced relative to the cobalt metal area is very high for the silica supported catalyst compared to the alumina and titania supported cobalt catalysts. Before the addition of ammonia, higher $\mathrm{CO}$ rates were observed per cobalt metal area for the silica supported catalyst, and similar $\mathrm{CO}$ rates were observed for the alumina and titania supported catalysts. Higher CO rates and higher ammonia feed rates of the silica supported catalyst per cobalt area is explained by the lower cobalt metal area. 
To understand the reason for the higher deactivation rate of the silica-supported catalyst as compared to the alumina and titania-supported catalysts, ammonia exposed catalysts were characterized by X-ray absorption near edge spectroscopy (XANES), and temperature programmed reduction (TPR). Temperature programmed reduction profiles of freshly calcined, and ammonia exposed during FTS, alumina, titania and silica-supported cobalt catalysts are shown in Figures 8-10, respectively. The TPR profile of the calcined alumina-supported cobalt catalyst shows two reduction peaks $\left(215\right.$ and $450{ }^{\circ} \mathrm{C}$ ) and a small hump at $250^{\circ} \mathrm{C}$, which can be attributed to the reduction of cobalt oxides [27,28], with the second step consuming three times as much $\mathrm{H}_{2}$ as the first step.

$$
\begin{array}{lll}
\mathrm{Co}_{3} \mathrm{O}_{4}+\mathrm{H}_{2} & \rightarrow & 3 \mathrm{CoO}+\mathrm{H}_{2} \mathrm{O} \\
3 \mathrm{CoO}+3 \mathrm{H}_{2} & \rightarrow & 3 \mathrm{Co}^{0}+3 \mathrm{H}_{2} \mathrm{O}
\end{array}
$$

The TPR profile of the ammonia exposed catalyst also displays two reduction peaks. Before measuring the TPR, the catalyst underwent a mild treatment at $300{ }^{\circ} \mathrm{C}$ under $1 \% \mathrm{O}_{2} / \mathrm{N}_{2}$ to remove the wax product formed from FTS. The peak at $310{ }^{\circ} \mathrm{C}$ corresponds to the reduction of surface oxide species and the other peak at $450{ }^{\circ} \mathrm{C}$ is similar to the peak observed for the calcined catalyst, whereas no other peaks were observed at higher temperature. The TPR profile of the calcined titania-supported cobalt catalyst also showed two reduction peaks $\left(110^{\circ} \mathrm{C}\right.$ and $37{ }^{\circ} \mathrm{C}$ ), these can be attributed to the $\mathrm{Co}_{3} \mathrm{O}_{4}$ to $\mathrm{CoO}$ and $\mathrm{CoO}$ to $\mathrm{Co}^{0}$, whereas, the ammonia exposed catalyst showed only one peak at $260^{\circ} \mathrm{C}$, and this peak is similar to the peak observed for the calcined catalyst. The TPR profile of the calcined silica-supported cobalt catalyst also displays two reduction peaks $\left(330^{\circ} \mathrm{C}\right.$ and $390{ }^{\circ} \mathrm{C}$ ), which can be attributed to the reduction of cobalt oxides, $\mathrm{Co}_{3} \mathrm{O}_{4} \rightarrow \mathrm{CoO}$ and $\mathrm{CoO} \rightarrow \mathrm{Co}^{0}$, respectively [27, 28]. The TPR profile of the ammonia exposed catalyst shows a broad peak with the deconvolution of three reduction peaks. 
Before measuring the TPR, the catalyst underwent a mild treatment at $300{ }^{\circ} \mathrm{C}$ under $1 \% \mathrm{O}_{2} / \mathrm{N}_{2}$ to remove the wax product formed from FTS. The peak at $310{ }^{\circ} \mathrm{C}$ is similar to the peak observed for the calcined catalyst, and two higher temperature peaks (one at $460{ }^{\circ} \mathrm{C}$ and another one at 500 ${ }^{\circ} \mathrm{C}$ ) were observed. The higher temperature peaks might be due to either the hydrogenation of FT hydrocarbon wax remaining with the catalyst or the reduction of cobalt support species (cobaltsilicates) formed after pore collapse.

An additional FTS experiment was conducted without adding any ammonia (a stable high CO conversion or clean run) by using a silica supported cobalt catalyst, to further confirm the higher temperature peaks. The catalyst was extracted similar to the ammonia addition case and followed by treating the catalyst at $300{ }^{\circ} \mathrm{C}$ under $1 \% \mathrm{O}_{2} / \mathrm{N}_{2}$ to remove any residual hydrocarbons. The TPR profile of the catalyst without ammonia exposure also displayed similar higher temperature peaks like those of the ammonia exposed catalyst. The higher temperature peak can be explained by some residual hydrocarbon wax remaining in catalyst particles, which undergo hydrogenation. These findings reveal that treatment at $300{ }^{\circ} \mathrm{C} / 4 \mathrm{~h}$ is insufficient to completely remove the hydrocarbon wax for the silica supported catalyst, whereas the higher temperature peaks were not observed for the ammonia exposed alumina and titania supported cobalt catalysts. Interestingly, used catalyst following the ammonia exposure during FTS (and subsequent extraction $/ 1 \% \mathrm{O}_{2}$ treatment) has a lower total area than the corresponding sample without ammonia exposure. If ammonia causes pore collapse, one would expect that there would be (a) less accessible cobalt oxide and (b) less residual hydrocarbon within pores. The lower total area and slight shift to higher temperature of the peaks for the ammonia exposed used sample compared to the used clean run sample, is consistent with some pore collapse caused by ammonia. 
Due to the complicated behavior of the hydrocarbon wax of the FT used catalysts, a low temperature $\left(60^{\circ} \mathrm{C}\right)$ ammonia pre-treatment study was conducted to further understand the effect of ammonia on various supports and supported cobalt catalysts. The samples (support or supported cobalt catalyst) were first spread on a watch glass, which was then placed into a Petri dish. A measured amount of concentrated aqueous ammonia (28 wt.\%) was added below the watch glass without touching the sample, and the dish was covered with another dish and sealed with parafilm, and then maintained in an oven at $60{ }^{\circ} \mathrm{C}$ for $18 \mathrm{~h}$. After that samples were dried at $110{ }^{\circ} \mathrm{C} / 3 \mathrm{~h}$. A portion of the silica supported catalyst was also treated at $300{ }^{\circ} \mathrm{C} / 4 \mathrm{~h}$ with air. The dried ammonia pre-treated catalysts were characterized by BET surface area and TPR measurements. BET surface area and pore characteristics of the alumina and titania supported catalysts were similar to their counterpart freshly calcined catalysts (Table 1). The BET surface area and average pore diameter of the calcined $\mathrm{SiO}_{2}$ support is $327 \mathrm{~m}^{2} / \mathrm{g}$ and $29.5 \mathrm{~nm}$, respectively, while the support after ammonia pre-treatment (dried) lost $33 \%$ of its BET surface area, with an increase of $52 \%$ in average pore diameter. The ammonia pre-treated calcined support lost $24 \%$ of its BET surface area, with an increase of $27 \%$ in pore diameter from its original value. The BET surface area and average pore diameter of the calcined $20 \% \mathrm{Co} / \mathrm{SiO}_{2}$ catalyst is $236 \mathrm{~m}^{2} / \mathrm{g}$ and $14.1 \mathrm{~nm}$, respectively, while after ammonia pre-treatment (both dried and calcined catalysts) lost $36 \%$ of their BET surface areas, with an increase of $\sim 42 \%$ in pore diameter from the original value. The higher average pore diameter values reflect losses of narrower pores likely due to pore collapse into the microporous range as detailed in the literature [32-34]. The pore size distributions (PSD) from the BJH method (Figure 11) for the calcined cobalt catalysts exhibit a narrower PSD; the $\mathrm{BJH}$ average pore diameter of the $20 \% \mathrm{Co} / \mathrm{SiO}_{2}$ catalyst was found to be $14.1 \mathrm{~nm}$, while that of the ammonia pretreated catalyst was increased to 
$20 \mathrm{~nm}$. Similar pore diameters were observed for the alumina and titania supported ammonia pre-treated catalysts and their freshly calcined counterparts. Temperature programmed reduction profiles of freshly calcined and ammonia pretreated alumina, titania and silica-supported cobalt catalysts are shown in Figures 8-10, respectively. The dried ammonia pretreated alumina and titania supported cobalt catalysts displayed similar peaks relative to the freshly calcined ones. The dried ammonia treated silica supported catalyst also displays three reduction peaks (350, 400 and $450{ }^{\circ} \mathrm{C}$ ); these can be attributed to the reduction of $\mathrm{Co}_{3} \mathrm{O}_{4}$ to $\mathrm{CoO}$ and $\mathrm{CoO}$ to $\mathrm{Co}^{0}$; the higher temperature peak may be due to the reduction of surface $\mathrm{CoO}$ contact with $\mathrm{NH}_{\mathrm{x}}$ species. After the calcination of the ammonia pretreated silica supported cobalt catalyst, a similar reduction profile to that of the freshly calcined catalyst was observed, albeit at slightly lower reduction temperatures. However, the total area of the reduction peaks was lower $(\sim 10 \%)$, suggesting losses in cobalt oxide possibly due to cobalt support compound formation (e.g., by pore collapse and encapsulation).

X-ray Absorption Near Edge Spectroscopy (XANES) was used to investigate the electronic structure of cobalt. Freshly reduced and ammonia-exposed alumina, titania and silicasupported cobalt catalysts were characterized by XANES. The normalized XANES spectra of the alumina and titania-supported cobalt catalysts underwent a slight increase in extent of reduction during $\mathrm{NH}_{3}$ exposure (Figures $\mathrm{S}_{1}-\mathrm{S}_{3}$ in supplementary information), whereas the silica-supported cobalt catalysts showed a significant difference for the ammonia exposed catalyst. Figure 12 display the XANES derivative spectra of (a) Co metal foil reference and (b) $0.5 \% \mathrm{Pt}-20 \% \mathrm{Co} / \mathrm{SiO}_{2}$ catalyst (solid line) before and (dashed line) after exposure to ammonia, respectively. The white line intensity of the Co catalyst before ammonia addition resembles that of the Co metal foil, although it is slightly higher likely due to the presence of strongly interacting CoO. After 
ammonia addition, the position of the edge moves to slightly (on the order of $1 \mathrm{eV}$ ) higher temperature, consistent with the formation of a fraction of an oxidized compound. Moreover, small features appear in the white line. Taking the derivative spectra, the differences become very clear. Following ammonia addition, there is a sharpening in the pre-edge feature, and two peaks emerge $(\sim 7.725 \mathrm{keV}$ and $\sim 7.734 \mathrm{keV})$ that are consistent with the formation of a cobalt support compound (e.g., $\mathrm{Co}_{2} \mathrm{SiO}_{4}$ ). A comparison with Figure 5 of reference [35], which provides XANES results for $\mathrm{Co}_{2} \mathrm{SiO}_{4}$ in the study of glazes of $16^{\text {th }}$ and $17^{\text {th }}$ century Chinese porcelains, provides further confirmation of this assessment. A detailed comparison of XANES spectra before and after $\mathrm{NH}_{3}$ exposure for all of three catalysts is included in the supplementary information section.

The addition of ammonia resulted in significant decreases in $\mathrm{CO}$ conversion for all the supported-cobalt catalysts, and the activity did not recover after the termination of ammonia cofeeding under normal FTS conditions, indicating that the catalyst had deactivated (e.g., $\mathrm{NH}_{\mathrm{x}}$ species are irreversibly adsorbed to deactivate cobalt active surface sites). The activity of alumina and titania-supported cobalt catalysts virtually recovered to the initial values after the catalysts had been subjected to a mild in-situ hydrogen treatment (i.e., similar conditions but the carbon monoxide was switched off) for a $24 \mathrm{~h}$ period (Figure 13). However, the activity of the silica-supported cobalt catalyst only partially recovered after the in-situ hydrogen treatment (Figure 14). The partial recovery of the catalytic activity of the silica-supported cobalt catalyst might be due to the collapse of narrow silica pores after exposure to ammonia, whereas the alumina and titania-supported catalysts virtually recovered to the initial condition (i.e., prior to exposure to ammonia) due to there being no significant pore collapse, and in turn, no significant formation of cobalt-support compounds. 
The effect of ammonia on the catalytic activity may be explained by the adsorption of $\mathrm{NH}_{\mathrm{x}}$ species on an operating catalyst in competition with hydrogen and $\mathrm{CO}$, thus changing the selectivity due to a coverage of $\mathrm{NH}_{\mathrm{x}}$ species on metal sites that normally adsorb hydrogen, creating a relatively hydrogen poor surface. After the addition of ammonia to the synthesis gas, the $\mathrm{H}_{2} / \mathrm{CO}$ usage ratio is slightly increased. From these results, it is further confirmed that the addition of ammonia generated a hydrogen poor surface. There are two likely possibilities for the beneficial impacts on selectivity (less methane and more $\mathrm{C}_{5}+$ ) with ammonia addition for the alumina and titania-supported cobalt catalysts; one is that ammonia may inhibit the methanation sites responsible for the deviation of methane selectivity above that produced from ASF kinetics; another possibility is that ammonia inhibits termination of chain growth. The evidence for the former is a slight decrease in the deviation from the ASF distribution for methane and the evidence for the latter is an increase in the value of $\alpha$.

The effect of ammonia (10 ppmv) on $\mathrm{CO}_{2}$ selectivity for the alumina, titania and silica supported-cobalt catalysts is shown in Figure 15. Carbon dioxide is mostly produced by the water gas shift (WGS) reaction from the primary byproduct, water, though it is generally accepted that the cobalt-metal particles display low intrinsic WGS activity. The $\mathrm{CO}_{2}$ selectivity for the alumina and titania supported cobalt catalysts was found to slightly decrease after the addition of ammonia. For the silica-supported catalyst, $\mathrm{CO}_{2}$ selectivity increased after the addition of ammonia. Higher carbon dioxide selectivity for the ammonia exposed silica catalyst is due to increased water gas shift, indicating that the oxidation state of a fraction of cobalt increases. The formation of cobalt-support compounds (i.e., having higher oxidation state compared to the metal) for the ammonia exposed silica-supported cobalt catalyst was confirmed by standard $\mathrm{H}_{2}$-TPR and XANES techniques. Higher carbon dioxide selectivity indicates higher 
water-gas shift reaction activity. Thus, there is a higher hydrogen partial pressure in the reactor, consistent with increased methane selectivity and a corresponding decreased $\mathrm{C}_{5}+$ selectivity. Similar findings were observed in our earlier work [36]; the $\mathrm{CO}_{2}$ selectivity increases as the amount of water is increased to the feed gas, due to some surface cobalt atoms having been reoxidized to form cobalt oxide, which subsequently formed cobalt support compounds. In our previous studies [37] on the effect of water addition to cobalt catalysts clearly suggests that, when water was added below $25 \%$ by volume, the catalytic activity decreased, but was recovered when water addition was terminated. XAS results indicated that the structure of the cobalt did not change, in agreement with the proposal that the effect of water at low partial pressures is kinetic and likely due to adsorption inhibition. However, at high water partial pressures of added water above $28 \%$ by volume, changes in the cobalt structure were readily observed. XANES suggested that cobalt aluminate-like species were formed, which was confirmed by considering the structural changes observed in the EXAFS Fourier Transform magnitude spectra.

\section{Conclusions}

The effect of ammonia was investigated during Fischer-Tropsch synthesis for alumina, titania and silica-supported cobalt catalysts. The addition of ammonia caused a significant step decrease in activity for all of the supported catalysts. The addition of ammonia had a positive effect on product selectivity (lower methane and higher $\mathrm{C}_{5}+$ ) for alumina and titania supported cobalt catalysts, whereas for the silica supported catalyst ammonia exposure causes an increase in methane and a decrease in $\mathrm{C}_{5}+$ selectivity. Silica supported catalyst exhibited a higher deactivation rate (activity) than the alumina and titania supported cobalt catalysts. The higher deactivation rate of the silica supported cobalt catalysts was studied by characterizing the catalysts collected under FTS conditions (before and after ammonia exposure) by porosity 
measurements, XANES spectroscopy. BET and pore size results of the ammonia pretreated silica supported catalyst revealed the collapse of narrow pores after exposure to ammonia. TPR and XANES results of the silica-supported cobalt catalyst reveal the formation of cobalt-support compounds. For the alumina and titania-supported cobalt catalysts, neither pore collapse nor the formation of cobalt-support compounds was observed after exposure to ammonia. The activity of the alumina and titania-supported cobalt catalysts virtually recovered to the initial state (i.e., prior to ammonia co-feeding) with mild in situ hydrogen treatment, whereas the silica supported catalyst activity only partially recovered with mild in situ hydrogen treatment. The silica supported catalyst behaved differently from other supports due to pore collapse to the microporous range and losses in the relative surface area during the exposure of ammonia even at low temperature. The instability of this high surface area silica support relative to the alumina and titania supports might be responsible for losses in porosity during ammonia exposure.

\section{Acknowledgments}

This work carried out at the CAER was supported by the Commonwealth of Kentucky. 


\section{References}

1. A.Y. Khodakov, W. Chu, P. Fongarland, Chem. Rev., 107 (2007) 1692.

2. Y. Zhang, L. Ma, T. Wang, X. Li, RSC Adv., 5 (2015) 45426.

3. Q. Yan, Y. Lu, C. Wan, J. Han, J. Rodriguez, J. Yin, F. Yu, Energy Fuels 28 (2014) 2027.

4. $\quad$ E. de Smit, B. M. Weckhuysen, Chem. Soc. Rev., 37 (2008) 2758.

5. Q. Zhang, J. Kang, Y. Wang, ChemCatChem, 2 (2010) 1030.

6. Y. Lu, B. Cao, F. Yu, J. Liu, Z. Bao, J. Gao, ChemCatChem, 6 (2014) 473.

7. S. Luo, L. Zeng, D. Xu, M. Kathe, E. Chung, N. Deshpande, L. Qin, A. Majumder, T. Hsieh, A. Tong, Z. Sun, L. Fan, Energy Environ. Sci., 7 (2014) 4104.

8. J. Wang, G. Cheng, Y. You, B. Xiao, S. Liu, P. He, D. Guo, X. Guo, G. Zhang, Int. J. Hydrogen Energy, 37 (2012) 6503.

9. A. Martinez, C. Lopez, F. Marquez, I. Diaz, J. Catal., 220 (2003) 486.

10. A.R. de la Osa, A. de Lucas, L. Sanchez-Silva, J. Diaz-Maroto, J.L. Valverde, P. Sanchez, Fuel, 95 (2012) 587.

11. W. Ma, G. Jacobs, D.E. Sparks, M.K. Gnanamani, V.R.R. Pendyala, C.H. Yen, J.L.S. Klettlinger, T.M. Tomsik, B.H. Davis, Fuel, 90 (2011) 756.

12. P.R. Karandikar, Y.J. Lee, G. Kwak, M.H. Woo, S.J. Park, H.G. Park, K.S. Ha, K.W. Jun, J. Phys. Chem. C, 118 (2014) 21975.

13. C.N. Hamelinck, A.P.C. Faaij, H. den Uil, H. Boerrigter, Energy, 29 (2004) 1743.

14. F.N. Cayan, M.J. Zhi, S.R. Pakalapati, I. Celik, N.Q. Wu, R. Gemmen, J. Power Sources, $185(2008) 595$. 
15. D.E. Sparks, G. Jacobs, M.K. Gnanamani, V.R.R. Pendyala, W. Ma, J. Kang, W.D. Shafer, R.A. Keogh, U.M. Graham, P. Gao, B.H. Davis, Catal. Today, 215 (2013) 67.

16. S.S. Pansare, J.D. Allison, Appl. Catal. A: Gen., 387 (2010) 224.

17. W. Ma, G. Jacobs, D.E. Sparks, V.R.R. Pendyala, S.G. Hopps, G.A. Thomas, H.H. Hamdeh, A. MacLennan, Y. Hu, B.H. Davis, J. Catal. 326 (2015) 149.

18. M. Claeys, E. van Steen, T. Sango, C. de Vries, R. Henke, A.K. Rausch, F. Roessner, $9^{\text {th }}$ Novel Gas Conversion Symposium, Lyon, France, 30 May-3 June, (2010).

19. Ø. Borg, N. Hammer, B.C. Enger, R. Myrstad, O.A. Lindvåg, S. Eri, T.H. Skagseth, E. Rytter, J. Catal. 279 (2011) 163.

20. P.J. van Berge, E.A. Caricato, Oral Presentation at Catalysis Society of South Africa (CATSA), Kruger National Park, South Africa, 2000.

21. S.C. LeViness, C.J. Mart, W.C. Behrmann, S.J. Hsia, D.R. Neskora, US 6,284,807 B1 (2001).

22. J. Inga, P. Kennedy, S. Leviness, WO 2005/071044 (2005).

23. V.R.R. Pendyala, M.K. Gnanamani, G. Jacobs, W. Ma, W.D. Shafer, B.H. Davis, Appl. Catal. A: Gen., 468 (2013) 38.

24. V.R.R. Pendyala, G. Jacobs, W. Ma, B.H. Davis, (2015) In: B.H. Davis, M.L. Occelli, (Eds) Fischer-Tropsch synthesis, catalysts, and catalysis: advances and applications. CRC Press, Boca Raton.

25. S. LeVinnes, C. Mart, W. Behrmann, S. Hsia, D. Neskora. Slurry hydrocarbon synthesis process with increased catalyst life. International: Patent WO 98/50487, 1998.

26. R.L. Espinoza, J.L. Visagie, P.J. van Berge, F.H. Bolder, US Patent 5,733,839 (1998). 
27. G. Jacobs, T.K. Das, Y. Zhang, J. Li, G. Racoillet, B.H. Davis, Appl. Catal. A: Gen., 233 (2002) 263.

28. G. Jacobs, Y. Ji, B.H. Davis, D.C. Cronauer, A.J. Kropf, C.L. Marshall, Appl. Catal. A: General 333 (2007) 177.

29. T. Jermwongratanachai, G. Jacobs, W. Ma, W.D. Shafer, M.K. Gnanamani, P. Gao, B. Kitiyanan, B.H. Davis, J.L.S. Klettlinger, C.H. Yen, D.C. Cronauer, A.J. Kropf, C.L. Marshall, Appl. Catal. A: General 464-465 (2013) 165-180.

30. K. Keyvanloo, M.J. Fisher, W.C. Hecker, R.J. Lancee, G. Jacobs, C.H. Bartholomew, J. Catal. 327 (2015) 33.

31. T. Ressler, J. Synchrotron Rad. 5 (1998) 118.

32. R. Xing, S.E. Rankin, Microporous and Mesoporous Materials 108 (2008) 65-76.

33. H.-P. Lin, C.-Y. Mou, S.-B. Liu, C.-Y. Tang, C.-Y. Lin, Micro. Meso. Mat.44-45 (2001) $129-137$.

34. Z.-Y. Yuan, J.-L. Blin, B.-L. Su. Chem. Commun. (2002) 504-505.

35. M.O. Figueiredo, T.P. Silva, J.P. Veiga, J. Electron Spectroscopy and Related Phen. 185 (2012) 97.

36. J. Li, X. Zhan, Y. Zhang, G. Jacobs, T.K. Das, B.H. Davis, Appl. Catal. A: Gen., 228 (2002) 203.

37. G. Jacobs, T.K. Das, P.M. Patterson, J. Li, L. Sanchez, B.H. Davis, Appl. Catal. A: Gen., 247 (2003) 335. 
Table 1: $\quad$ BET surface area and pore size distribution results of the supports and supported cobalt catalysts.

\begin{tabular}{|c|c|c|c|c|c|c|}
\hline Catalyst & $\begin{array}{c}\text { BET Surface } \\
\text { Area } \\
\left(\mathrm{m}^{2} / \mathrm{g}\right) \\
\end{array}$ & $\begin{array}{l}\text { SP Pore } \\
\text { Volume } \\
\left(\mathrm{cm}^{3} / \mathrm{g}\right)\end{array}$ & $\begin{array}{l}\text { SP Pore } \\
\text { Diam. } \\
(\mathbf{n m})\end{array}$ & $\begin{array}{c}\text { BJH Pore } \\
\text { Volume }\left(\mathrm{cm}^{3} / \mathrm{g}\right) \\
\text { Ads } / \text { Des } \\
\end{array}$ & $\begin{array}{c}\text { BJH Pore } \\
\text { Diam. (nm) } \\
\text { Ads / Des) } \\
\end{array}$ & $\begin{array}{c}\text { BET SA } \\
\text { Ratio with } \\
\text { fresh case } \\
\end{array}$ \\
\hline $\begin{array}{c}\gamma-\mathrm{Al}_{2} \mathrm{O}_{3} \text { support } \\
(\text { Catalox Sba } 150)\end{array}$ & 140 & 0.442 & 12.7 & $0.439 / 0.445$ & $11.8 / 9.7$ & - \\
\hline $\begin{array}{c}\text { Ammonia pretreated } \\
\mathrm{Al}_{2} \mathrm{O}_{3} \text { support }\end{array}$ & 142 & 0.419 & 11.8 & $0.414 / 0.422$ & $11.4 / 9.7$ & 1.01 \\
\hline $\begin{array}{c}\text { Calcined } \\
0.5 \% \mathrm{Pt}-25 \% \mathrm{Co} / \mathrm{Al}_{2} \mathrm{O}_{3}\end{array}$ & 96 & 0.237 & 9.9 & $0.232 / 0.236$ & $10.3 / 9.5$ & - \\
\hline $\begin{array}{c}\text { Ammonia pretreated } \\
0.5 \% \mathrm{Pt}-25 \% \mathrm{Co} / \mathrm{Al}_{2} \mathrm{O}_{3}\end{array}$ & 97 & 0.233 & 9.5 & $0.228 / 0.231$ & $10.3 / 9.4$ & 1.01 \\
\hline $\begin{array}{c}\mathrm{TiO}_{2} \text { support } \\
\text { (Degussa P-25) }\end{array}$ & 50 & 0.389 & 31.4 & $0.388 / 0.390$ & $31.9 / 28.8$ & - \\
\hline $\begin{array}{c}\text { Ammonia pretreated } \\
\mathrm{TiO}_{2} \text { support }\end{array}$ & 50 & 0.386 & 31.2 & $0.386 / 0.387$ & $32.3 / 28.4$ & 1.0 \\
\hline $\begin{array}{c}\text { Calcined } \\
0.2 \% \mathrm{Pt}-10 \% \mathrm{Co} / \mathrm{TiO}_{2}\end{array}$ & 42 & 0.274 & 25.9 & $0.279 / 0.275$ & $26.5 / 25.0$ & - \\
\hline $\begin{array}{l}\text { Ammonia pretreated } \\
0.2 \% \mathrm{Pt}-10 \% \mathrm{Co} / \mathrm{TiO}_{2}\end{array}$ & 42 & 0.273 & 25.8 & $0.274 / 0.275$ & $26.7 / 25.0$ & 1.0 \\
\hline $\begin{array}{c}\mathrm{SiO}_{2} \text { support } \\
(\mathrm{PQ}-\mathrm{CS} 2133)\end{array}$ & 327 & 2.41 & 29.5 & $2.93 / 2.42$ & $34.0 / 23.3$ & - \\
\hline $\begin{array}{l}\text { Ammonia pretreated } \\
\mathrm{SiO}_{2} \text { support (dried) }\end{array}$ & 220 & 2.46 & 44.8 & $2.45 / 2.47$ & 43.8 / 26.5 & 0.673 \\
\hline $\begin{array}{c}\text { Ammonia pretreated } \\
\mathrm{SiO}_{2} \text { support (calcined) }\end{array}$ & 250 & 2.34 & 37.4 & $2.31 / 2.34$ & 44.5 / 28.0 & 0.765 \\
\hline $\begin{array}{c}\text { Calcined } \\
20 \% \mathrm{Co} / \mathrm{SiO}_{2}\end{array}$ & 236 & 0.799 & 14.1 & $0.780 / 0.803$ & $14.6 / 12.0$ & - \\
\hline $\begin{array}{l}\text { Ammonia pretreated } \\
20 \% \mathrm{Co} / \mathrm{SiO}_{2}(\text { dried })\end{array}$ & 150 & 0.753 & 20.1 & $0.738 / 0.751$ & $22.9 / 19.3$ & 0.636 \\
\hline $\begin{array}{c}\text { Ammonia pretreated } \\
20 \% \mathrm{Co} / \mathrm{SiO}_{2} \text { (calcined) }\end{array}$ & 152 & 0.757 & 19.9 & $0.740 / 0.756$ & $23.3 / 19.2$ & 0.644 \\
\hline
\end{tabular}


Table 2: Hydrogen chemisorption results of various supported cobalt catalysts.

\begin{tabular}{|c|c|c|c|c|c|}
\hline Catalyst & $\begin{array}{c}\mathbf{H}_{2} \\
\text { desorbed } \\
\left(\boldsymbol{\mu m o l} / \mathbf{g}_{\text {cat }}\right)\end{array}$ & $\begin{array}{c}\mathbf{O}_{2} \text { uptake } \\
\left(\boldsymbol{\mu m o l} / \mathbf{g}_{\text {cat }}\right)\end{array}$ & $\begin{array}{c}\text { Corrected } \\
\text { dispersion } \\
(\%)\end{array}$ & $\begin{array}{c}\text { Corrected } \\
\text { diameter } \\
(\mathbf{n m})\end{array}$ & $\begin{array}{c}\text { Reduction } \\
\mathbf{( \% )}\end{array}$ \\
\hline $0.5 \% \mathrm{Pt}-25 \% \mathrm{Co} / \mathrm{Al}_{2} \mathrm{O}_{3}$ & 125 & 1700 & 9.6 & 10.8 & 60.1 \\
\hline $0.2 \% \mathrm{Pt}-10 \% \mathrm{Co} / \mathrm{TiO}_{2}$ & 64.7 & 860.3 & 10.0 & 10.3 & 76.1 \\
\hline $20 \% \mathrm{Co} / \mathrm{SiO}_{2}$ & 32.7 & 1600 & 2.7 & 38 & 71.0 \\
\hline
\end{tabular}

${ }^{\mathrm{a}}$ Hydrogen reduction at $350^{\circ} \mathrm{C} / 12 \mathrm{~h}$ 
Table 3: $\quad$ Chain growth probability $(\alpha)$ values of various supported cobalt catalysts before and after the addition of ammonia.

\begin{tabular}{|c|c|c|}
\hline \multirow[b]{2}{*}{ Catalyst } & \multicolumn{2}{|c|}{ Chain growth probability ( $\alpha)$} \\
\hline & $\begin{array}{c}\text { Before addition of ammonia } \\
(0 \text { ppmv })\end{array}$ & $\begin{array}{c}\text { After addition of ammonia } \\
(10 \mathrm{ppmv})\end{array}$ \\
\hline $0.5 \% \mathrm{Pt}-25 \% \mathrm{Co} / \mathrm{Al}_{2} \mathrm{O}_{3}$ & 0.85 & 0.87 \\
\hline $0.2 \% \mathrm{Pt}-10 \% \mathrm{Co} / \mathrm{TiO}_{2}$ & 0.88 & 0.92 \\
\hline $20 \% \mathrm{Co} / \mathrm{SiO}_{2}$ & 0.83 & 0.84 \\
\hline
\end{tabular}


Table 4: $\quad$ Metal area of cobalt, ammonia introduction and CO rates of various supported cobalt catalysts.

\begin{tabular}{|c|c|c|c|c|}
\hline \multirow{2}{*}{ Catalyst } & \multirow{2}{*}{$\begin{array}{c}\text { Metal area of } \\
\text { cobalt }(\quad)\end{array}$} & $\begin{array}{c}\text { Amount of } \mathbf{N H}_{\mathbf{3}} \\
\text { introduced } \\
(\boldsymbol{\mu} \mathbf{L} / \mathbf{h} / \quad)\end{array}$ & \multicolumn{2}{|c|}{ CO rate } \\
\cline { 4 - 5 } & & & $\begin{array}{c}\text { (mole/sec/ } \\
\text { Before } \mathbf{N H}_{3} \\
\text { addition }\end{array}$ & $\begin{array}{c}\text { After } \mathbf{N H}_{\mathbf{3}} \\
\text { addition }\end{array}$ \\
\hline $0.5 \% \mathrm{Pt}-25 \% \mathrm{Co} / \mathrm{Al}_{2} \mathrm{O}_{3}$ & 39.87 & 0.94 & 7.5 & 5.0 \\
\hline $0.2 \% \mathrm{Pt}-10 \% \mathrm{Co} / \mathrm{TiO}_{2}$ & 51.60 & 0.54 & 8.1 & 5.1 \\
\hline $20 \% \mathrm{Co} / \mathrm{SiO}_{2}$ & 13.04 & 3.07 & 33.0 & 9.6 \\
\hline
\end{tabular}




\section{Figure Captions}

Figure 1: The effect of 10 ppmv ammonia $\left(\mathrm{NH}_{3}\right)$ addition on $\mathrm{CO}$ conversion for the alumina supported cobalt catalyst.

$\left(\mathrm{T}=220^{\circ} \mathrm{C}, \mathrm{P}=1.9 \mathrm{MPa}, \mathrm{H}_{2} / \mathrm{CO}=2, \mathrm{SV}=4 \mathrm{SL} / \mathrm{g}_{\text {catalyst }} / \mathrm{h}\right)$

Figure 2: The effect of 10 ppmv ammonia $\left(\mathrm{NH}_{3}\right)$ addition on product selectivity for the alumina supported cobalt catalyst.

$\left(\mathrm{T}=220^{\circ} \mathrm{C}, \mathrm{P}=1.9 \mathrm{MPa}, \mathrm{H}_{2} / \mathrm{CO}=2, \mathrm{SV}=4 \mathrm{SL} / \mathrm{g}_{\text {catalys }} / \mathrm{h}\right)$

Figure 3: The effect of 10 ppmv ammonia $\left(\mathrm{NH}_{3}\right)$ addition on $\mathrm{CO}$ conversion for the titania supported cobalt catalyst.

$\left(\mathrm{T}=220^{\circ} \mathrm{C}, \mathrm{P}=1.9 \mathrm{MPa}, \mathrm{H}_{2} / \mathrm{CO}=2, \mathrm{SV}=3 \mathrm{SL} / \mathrm{g}_{\text {catalyst }} / \mathrm{h}\right)$

Figure 4: $\quad$ The effect of 10 ppmv ammonia $\left(\mathrm{NH}_{3}\right)$ addition on product selectivity for the titania supported cobalt catalyst.

$\left(\mathrm{T}=220^{\circ} \mathrm{C}, \mathrm{P}=1.9 \mathrm{MPa}, \mathrm{H}_{2} / \mathrm{CO}=2, \mathrm{SV}=3 \mathrm{SL} / \mathrm{g}_{\text {catalyst }} / \mathrm{h}\right)$

Figure 5: $\quad$ The effect of 10 ppmv ammonia $\left(\mathrm{NH}_{3}\right)$ addition on $\mathrm{CO}$ conversion for the silica supported cobalt catalyst.

$\left(\mathrm{T}=220^{\circ} \mathrm{C}, \mathrm{P}=1.9 \mathrm{MPa}, \mathrm{H}_{2} / \mathrm{CO}=2, \mathrm{SV}=4 \mathrm{SL} / \mathrm{g}_{\text {catalyst }} / \mathrm{h}\right)$

Figure 6: The effect of 10 ppmv ammonia $\left(\mathrm{NH}_{3}\right)$ addition on product selectivity for the silica supported cobalt catalyst.

$\left(\mathrm{T}=220^{\circ} \mathrm{C}, \mathrm{P}=1.9 \mathrm{MPa}, \mathrm{H}_{2} / \mathrm{CO}=2, \mathrm{SV}=4 \mathrm{SL} / \mathrm{g}_{\text {catalyst }} / \mathrm{h}\right)$

Figure 7: Effect of $\mathrm{NH}_{3}$ addition on relative $\mathrm{CO}$ conversion, related to the pre-exposure conditions.

Figure 8: Temperature programmed reduction profiles of $0.5 \% \mathrm{Pt}-25 \% \mathrm{Co} / \mathrm{Al}_{2} \mathrm{O}_{3}$ catalyst.
(a) Freshly calcined
(b) $\mathrm{NH}_{3}$ pre-treated (dried)
(c) $\mathrm{NH}_{3}$ exposed during the FTS

Figure 9: Temperature programmed reduction profiles of $0.2 \% \mathrm{Pt}-10 \% \mathrm{Co} / \mathrm{TiO}_{2}$ catalyst.
(a) Freshly calcined
(b) $\mathrm{NH}_{3}$ pre-treated (dried)
(c) $\mathrm{NH}_{3}$ exposed during the FTS

Figure 10: Temperature programmed reduction profiles of $20 \% \mathrm{Co} / \mathrm{SiO}_{2}$ catalyst.
(a) Freshly calcined
(b) $\mathrm{NH}_{3}$ pre-treated (solid line is dried, dashed line is calcined)
(c) $\mathrm{NH}_{3}$ exposed during the FTS
(d) FT used (without $\mathrm{NH}_{3}$ exposure)

Figure 11: Pore size distribution from BJH adsorption measurements of nitrogen adsorption for various catalysts.
(A) (a) Alumina support
(b) $\mathrm{NH}_{3}$ pretreated alumina support
(c) Co/alumina-calcined
(d) $\mathrm{NH}_{3}$ pretreated Co/alumina
(B) (a) Titania support
(b) $\mathrm{NH}_{3}$ pretreated titania support
(c) $\mathrm{Co} /$ titania-calcined
(d) $\mathrm{NH}_{3}$ pretreated $\mathrm{Co} /$ titania
(C) (a) silica support $\quad$ (b) $\mathrm{NH}_{3}$ pretreated silica support (c) Co/silica-calcined 
(d) $\mathrm{NH}_{3}$ pretreated $\mathrm{Co} /$ silica-dried (e) $\mathrm{NH}_{3}$ pretreated $\mathrm{Co} /$ silica-calcined (f) Repeat Co/silica-calcined

Figure 12: Corresponding XANES derivative spectra of (a) Co metal foil reference and (b) $20 \% \mathrm{Co} / \mathrm{SiO}_{2}$ catalyst (solid line) before and (dashed line) after exposure to ammonia.

Figure 13: Run including ammonia addition and hydrogen treatment for the alumina supported cobalt catalyst.

Figure 14: Run including ammonia addition and hydrogen treatment for the silica supported cobalt catalyst.

Figure 15: The effect of 10 ppmv ammonia $\left(\mathrm{NH}_{3}\right)$ addition on $\mathrm{CO}_{2}$ selectivity for the alumina, titania and silica supported-cobalt catalysts. 


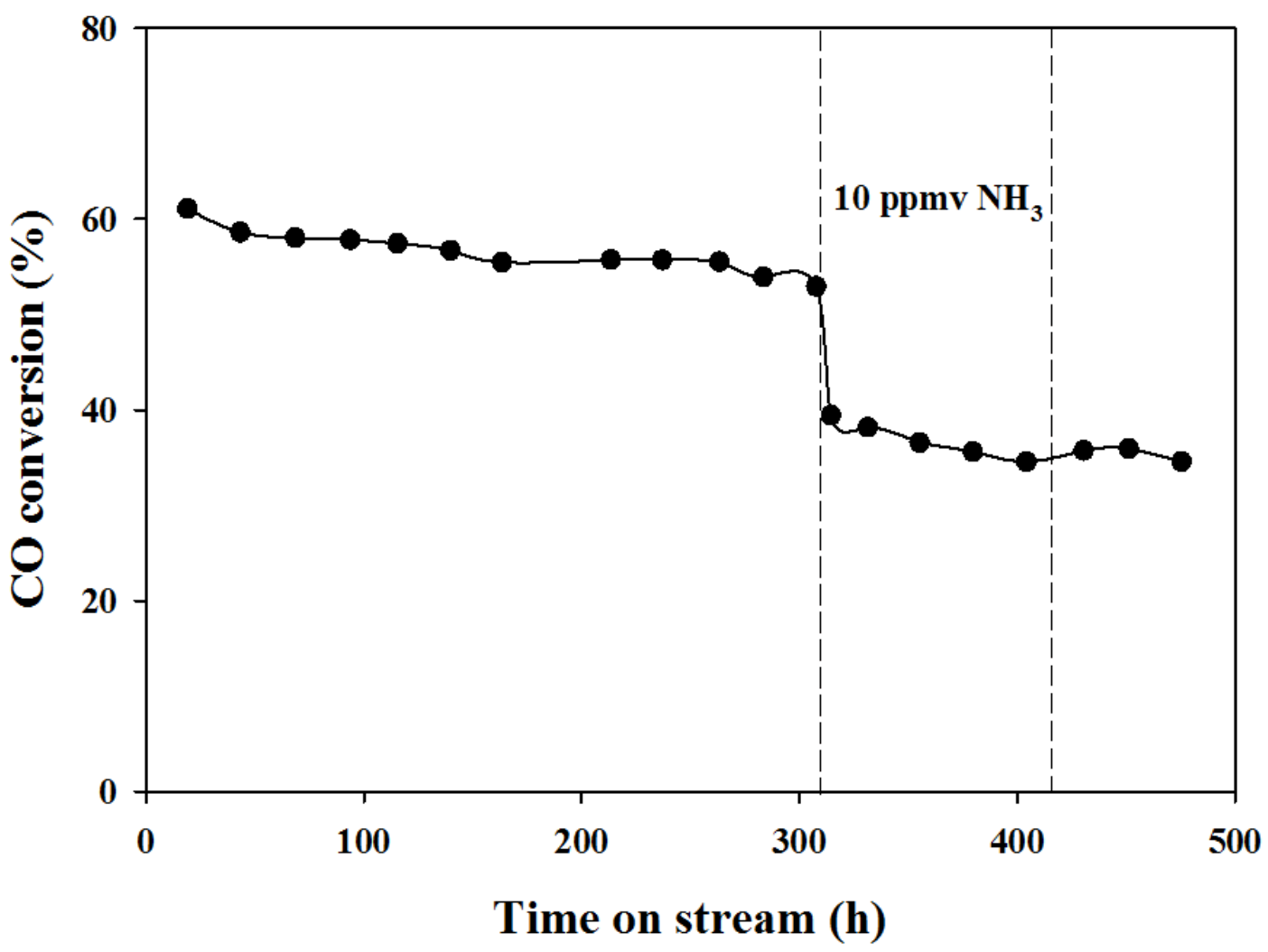

Figure 1 


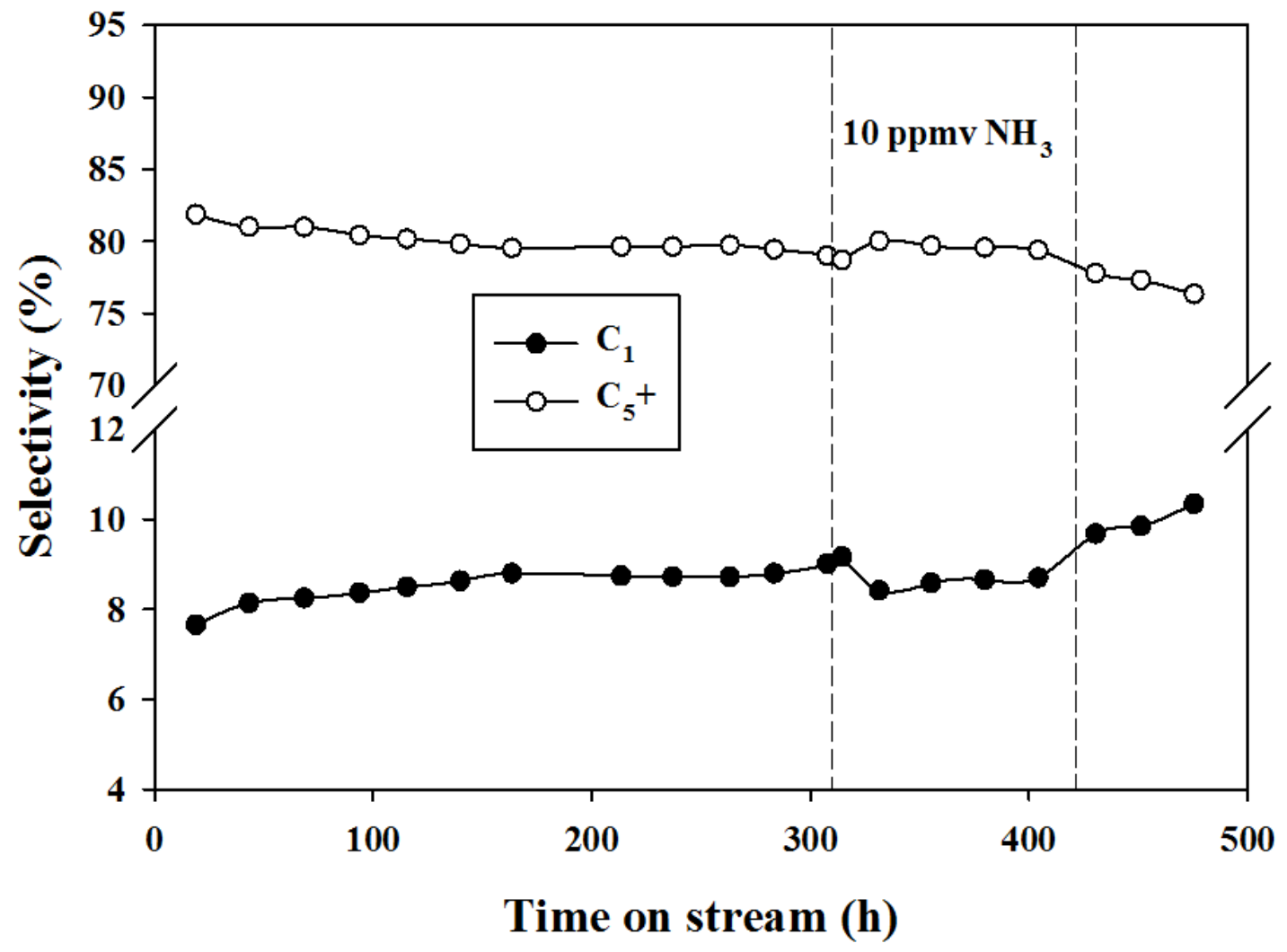

Figure 2 


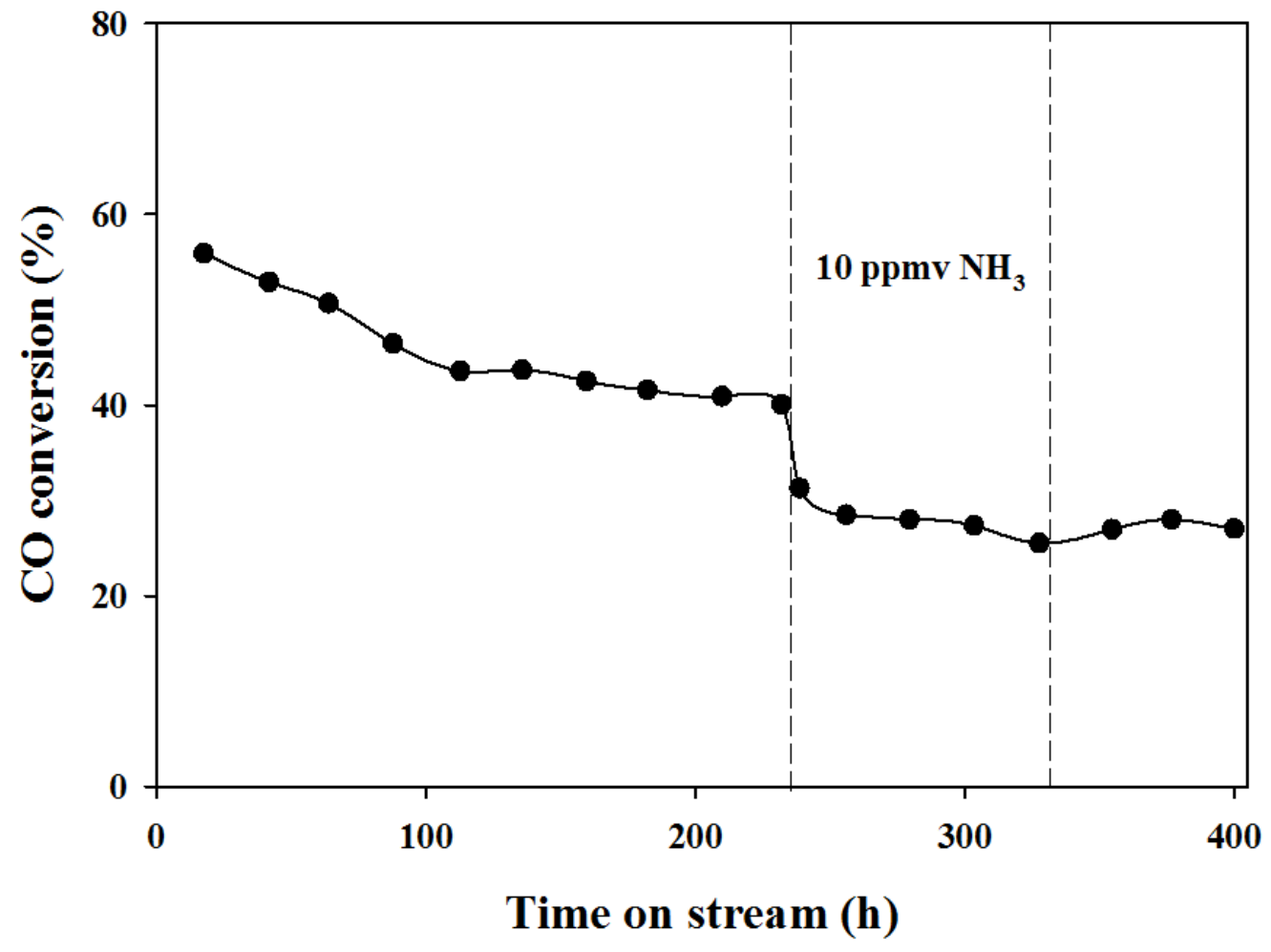

Figure 3 


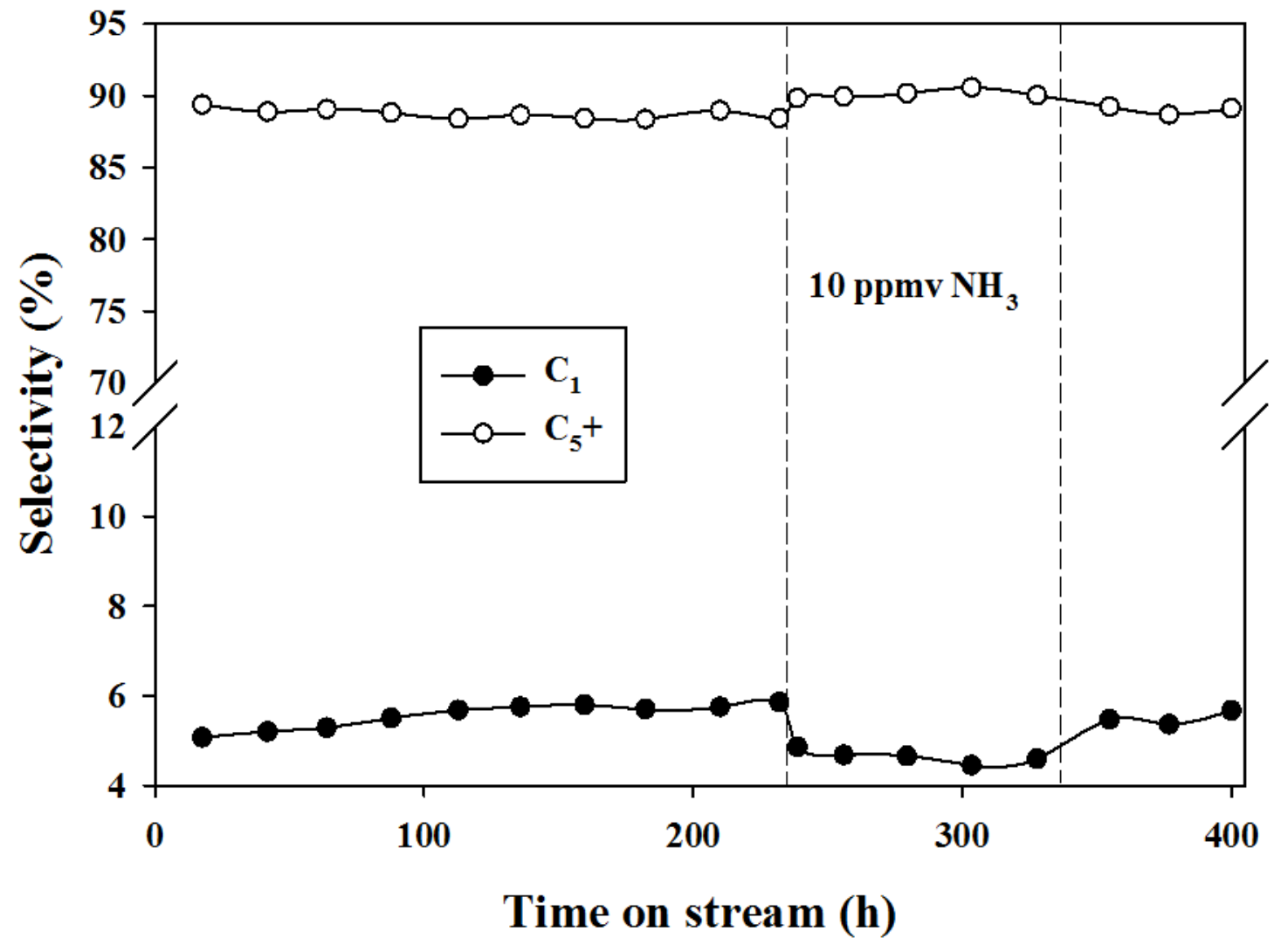

Figure 4 


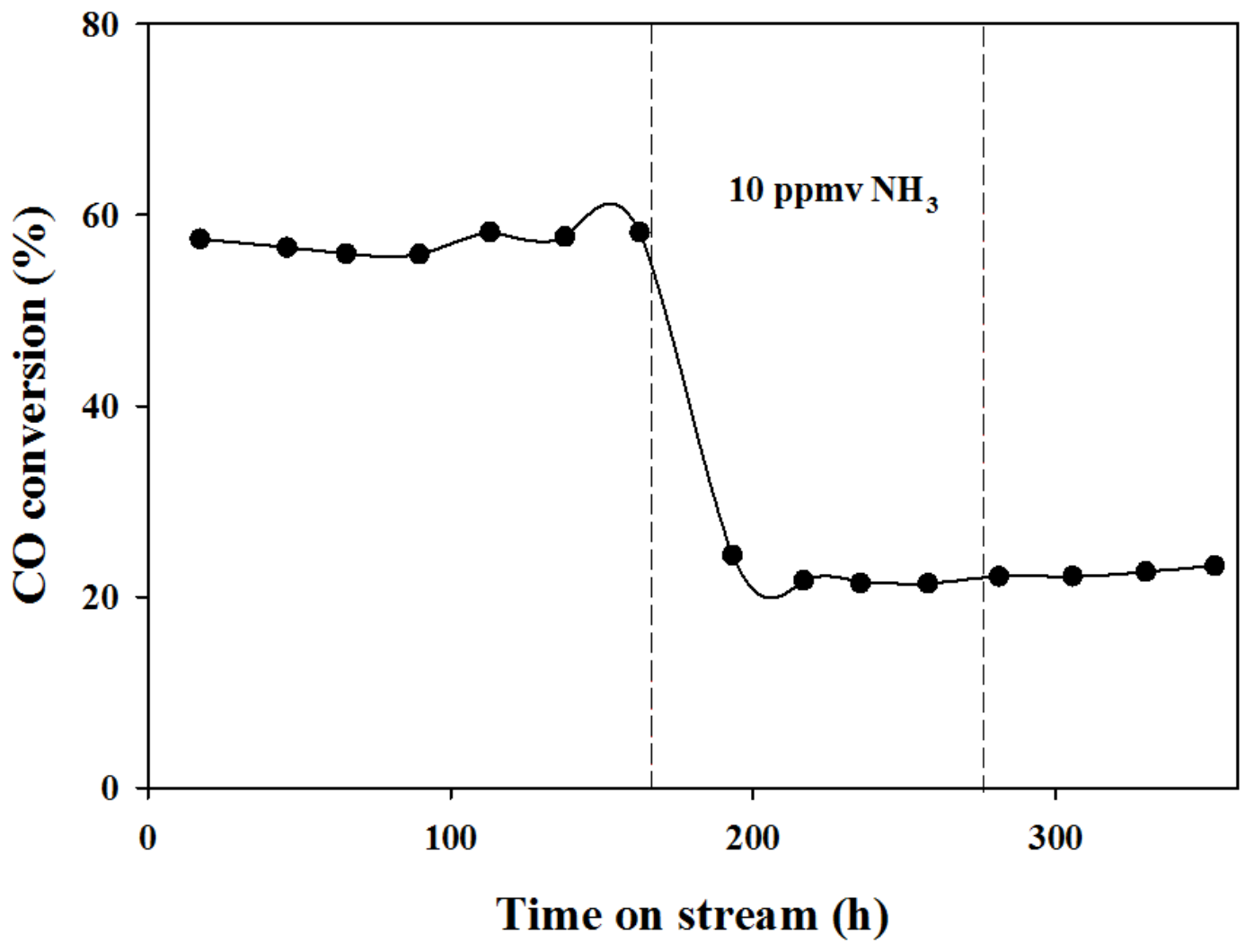

Figure 5 


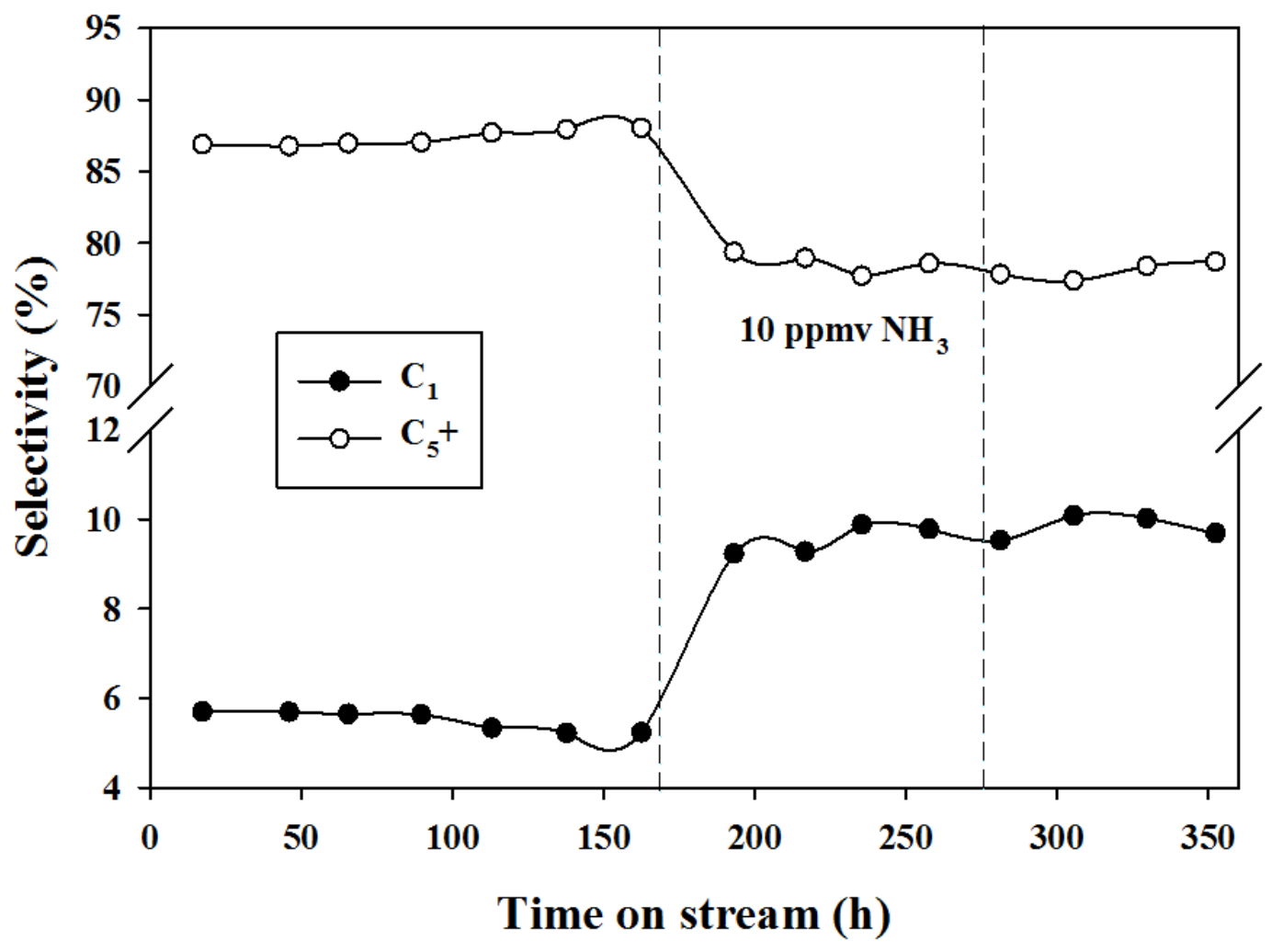

Figure 6 


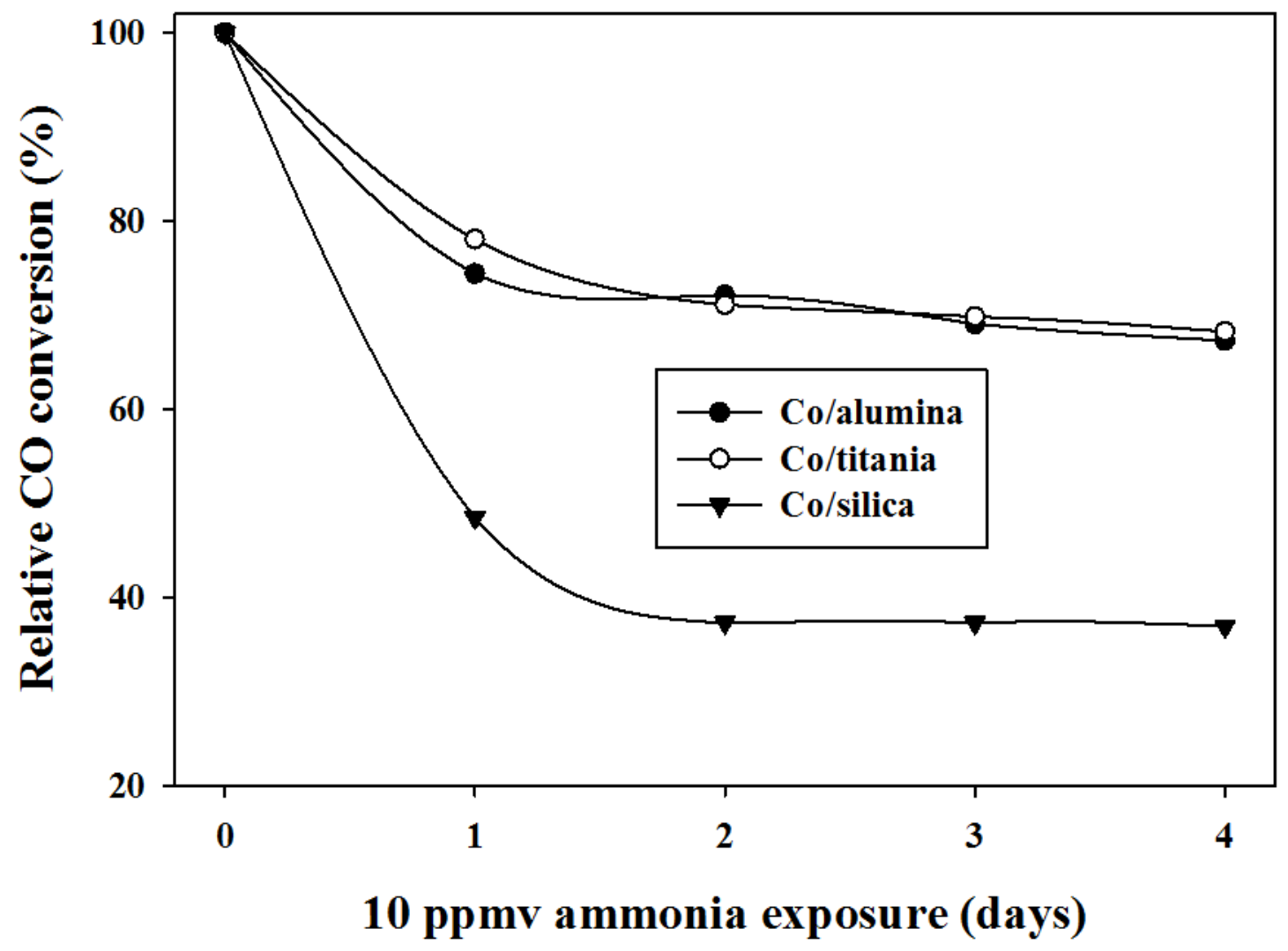

Figure 7 


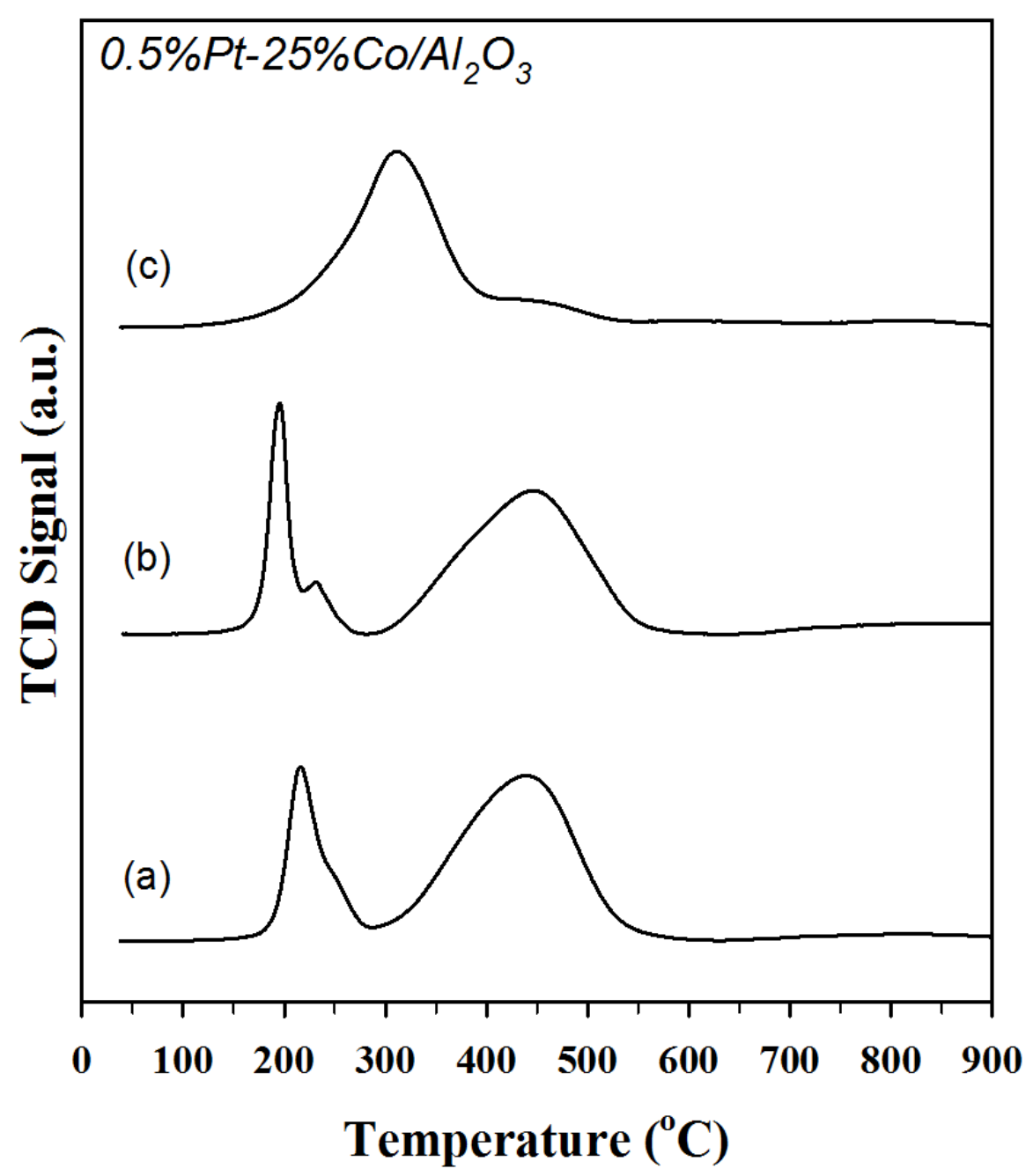

Figure 8 


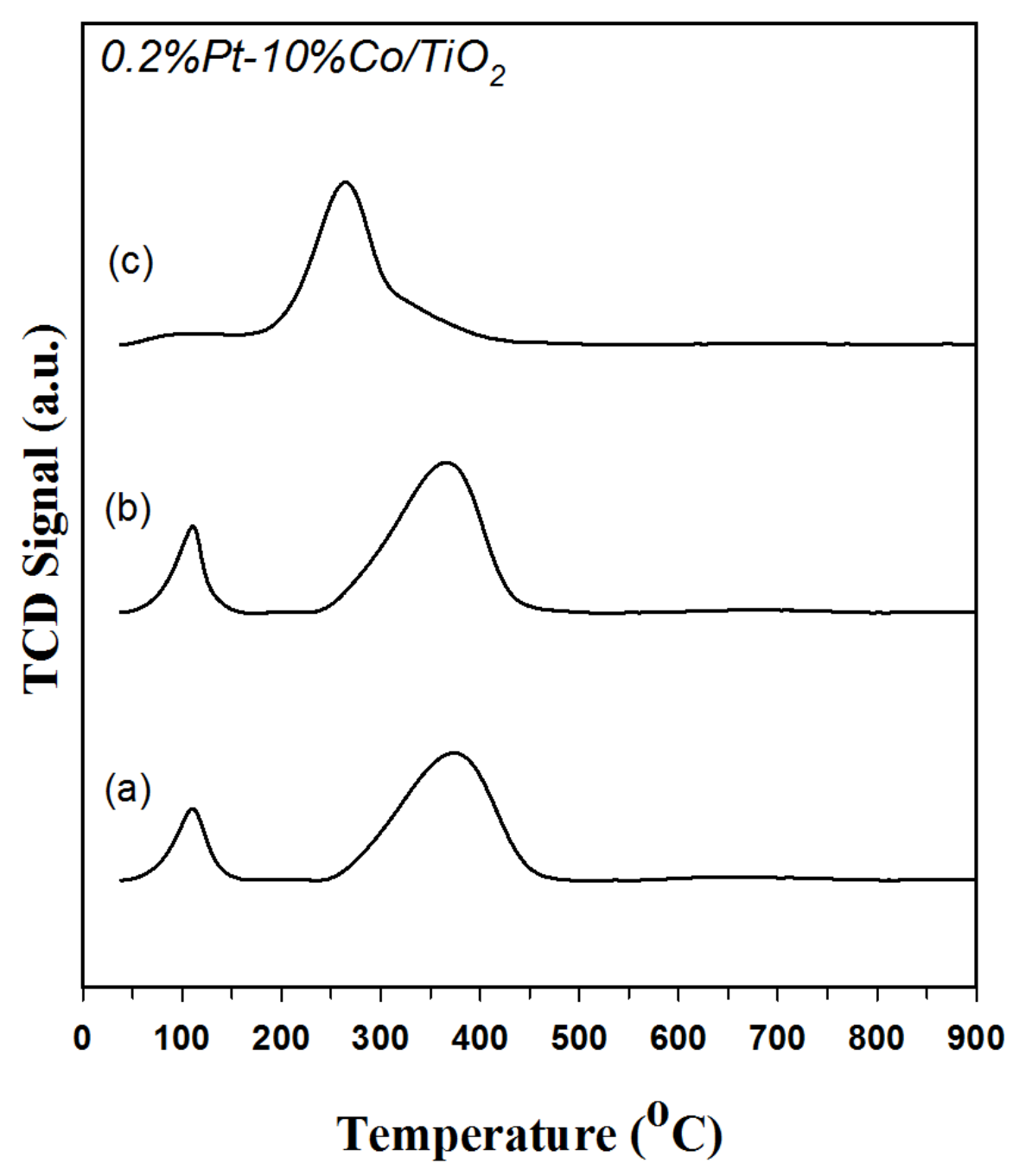

Figure 9 


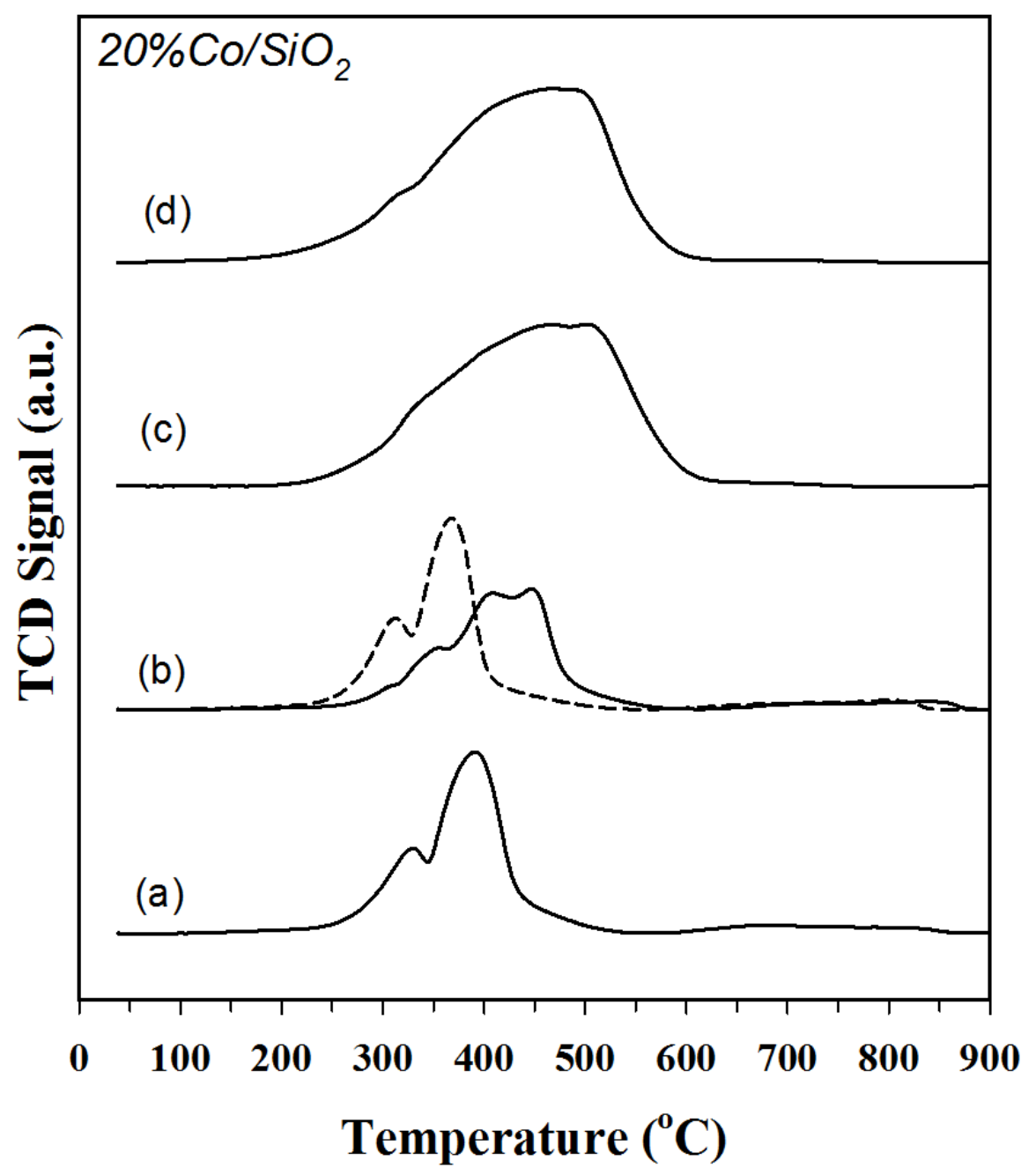

Figure 10 

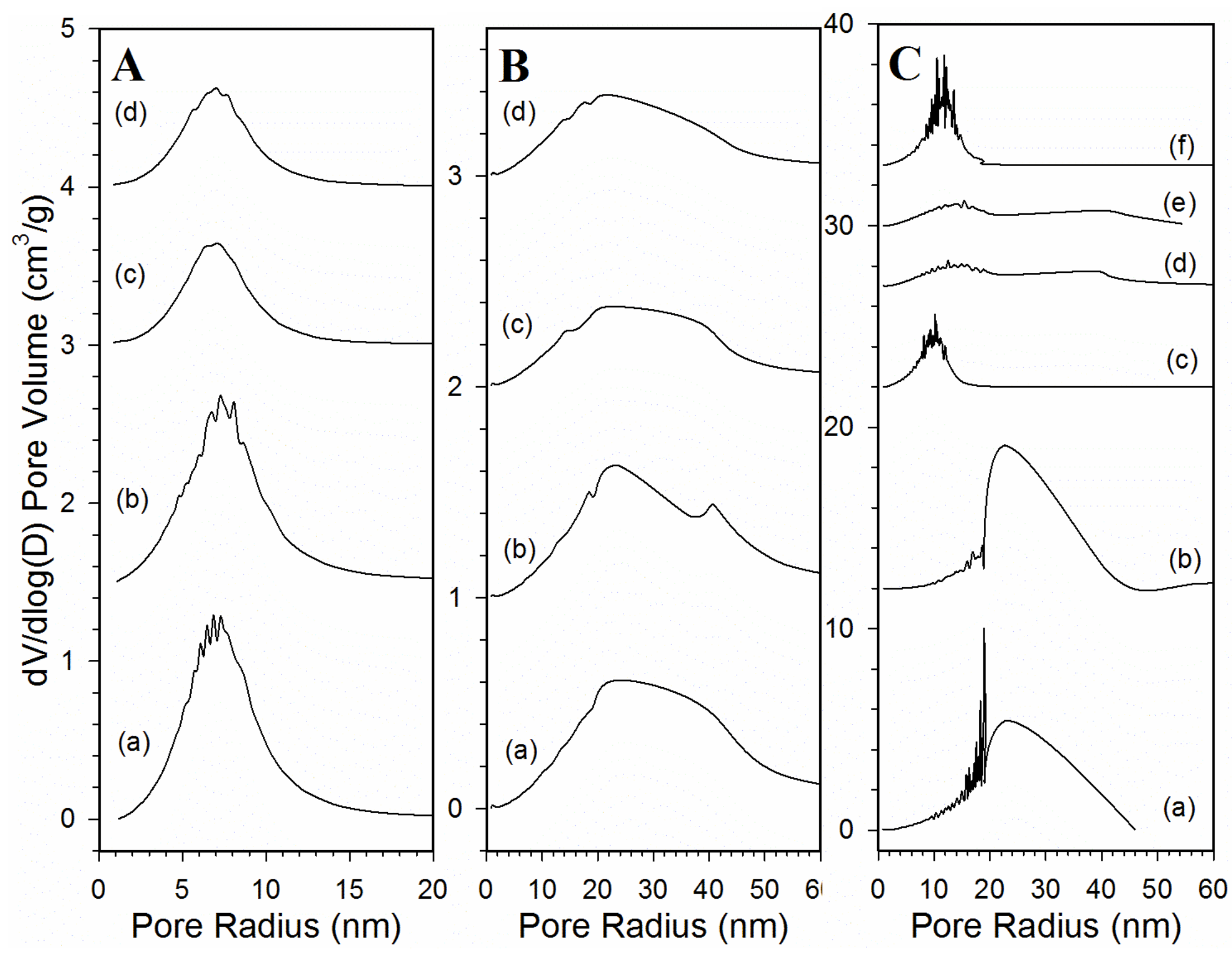

Figure 11 


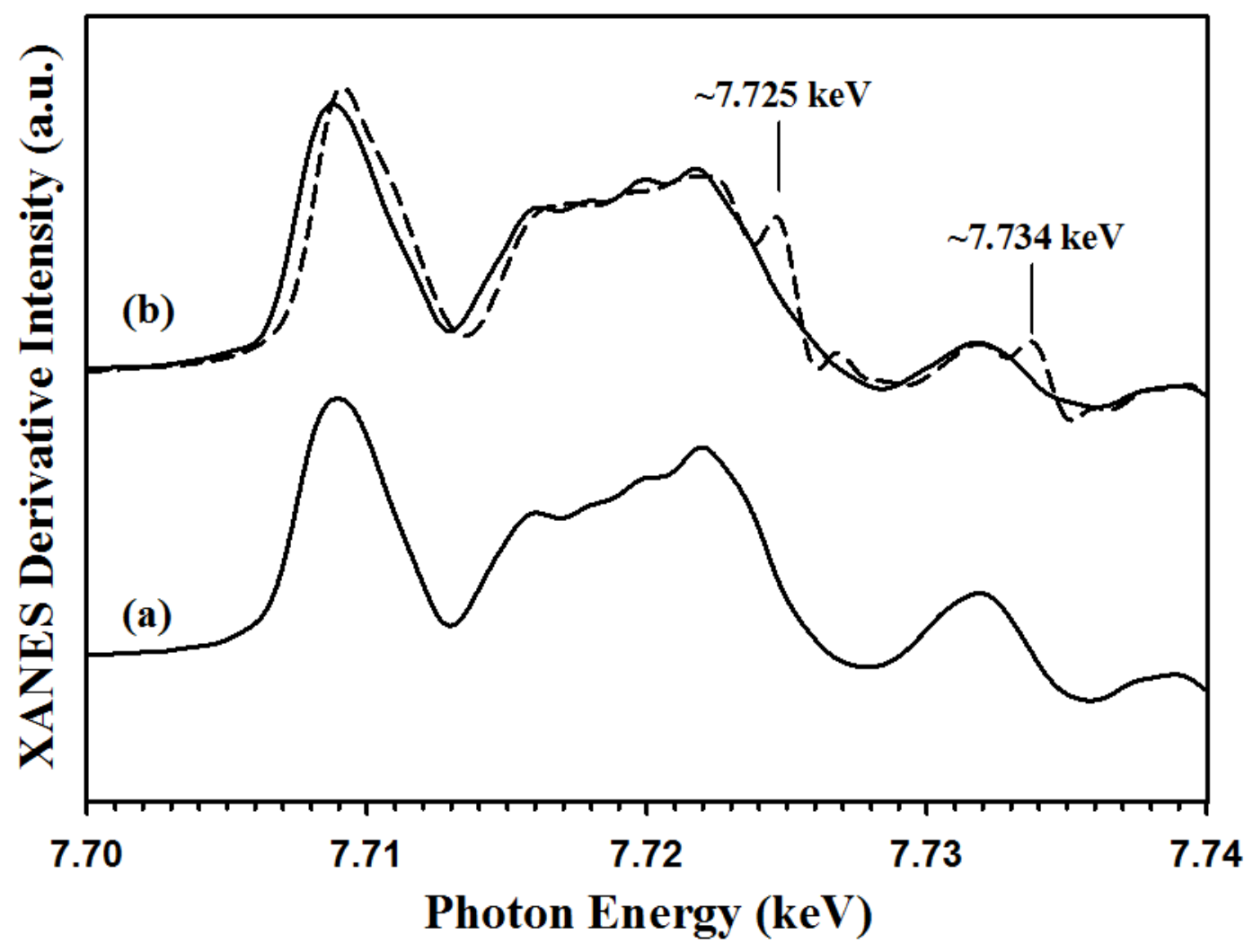

Figure 12 


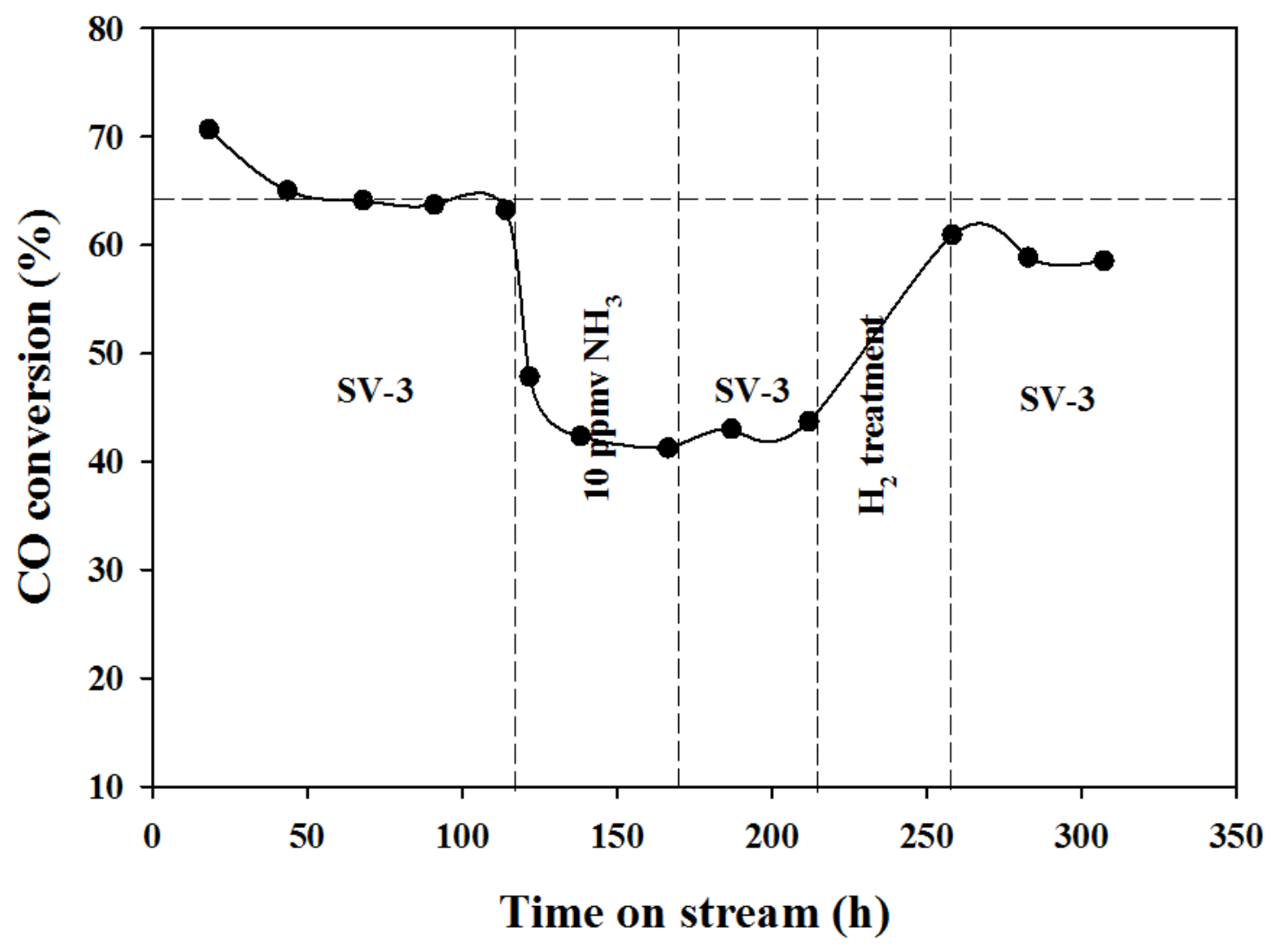

Figure 13 


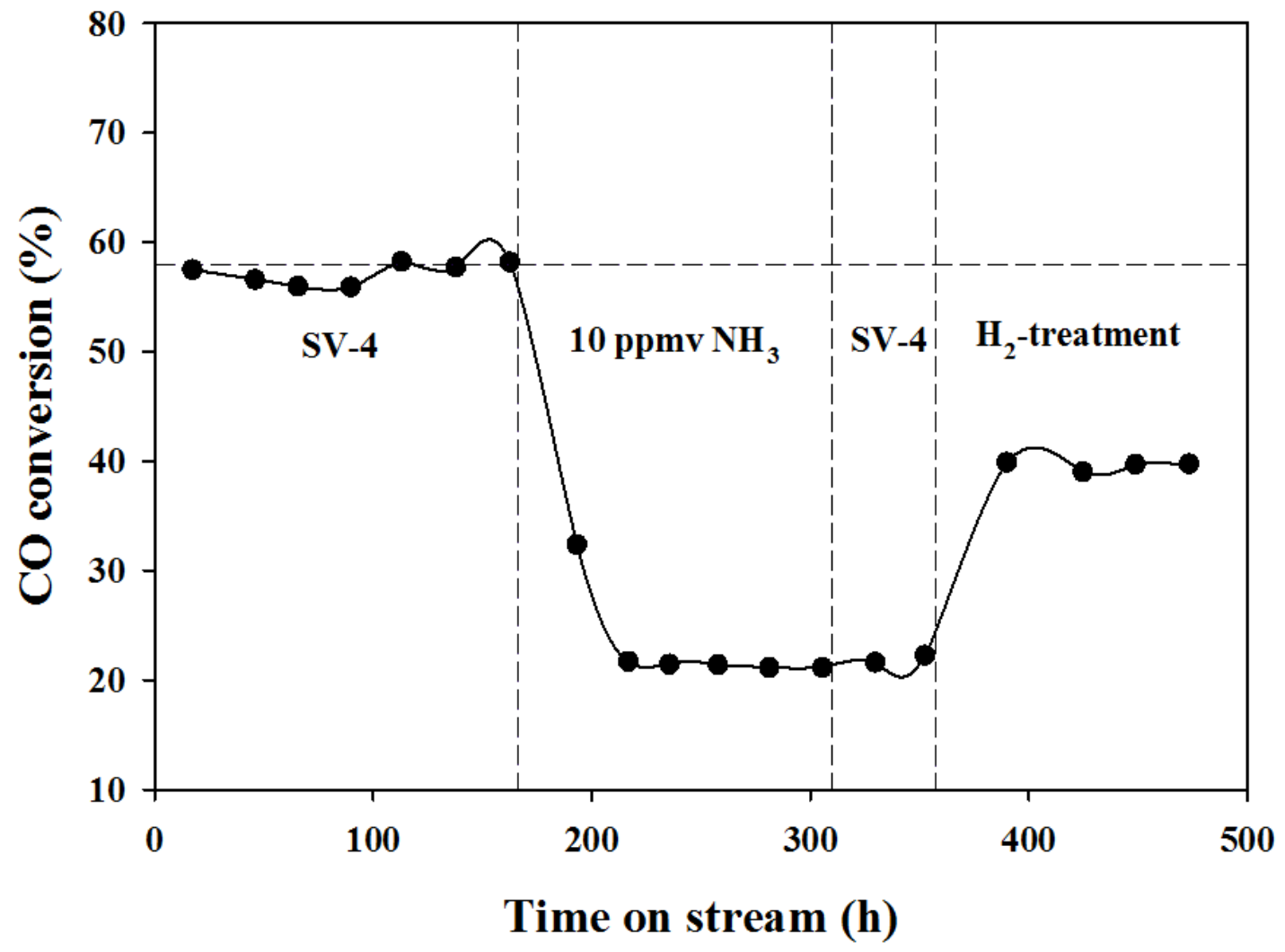

Figure 14 


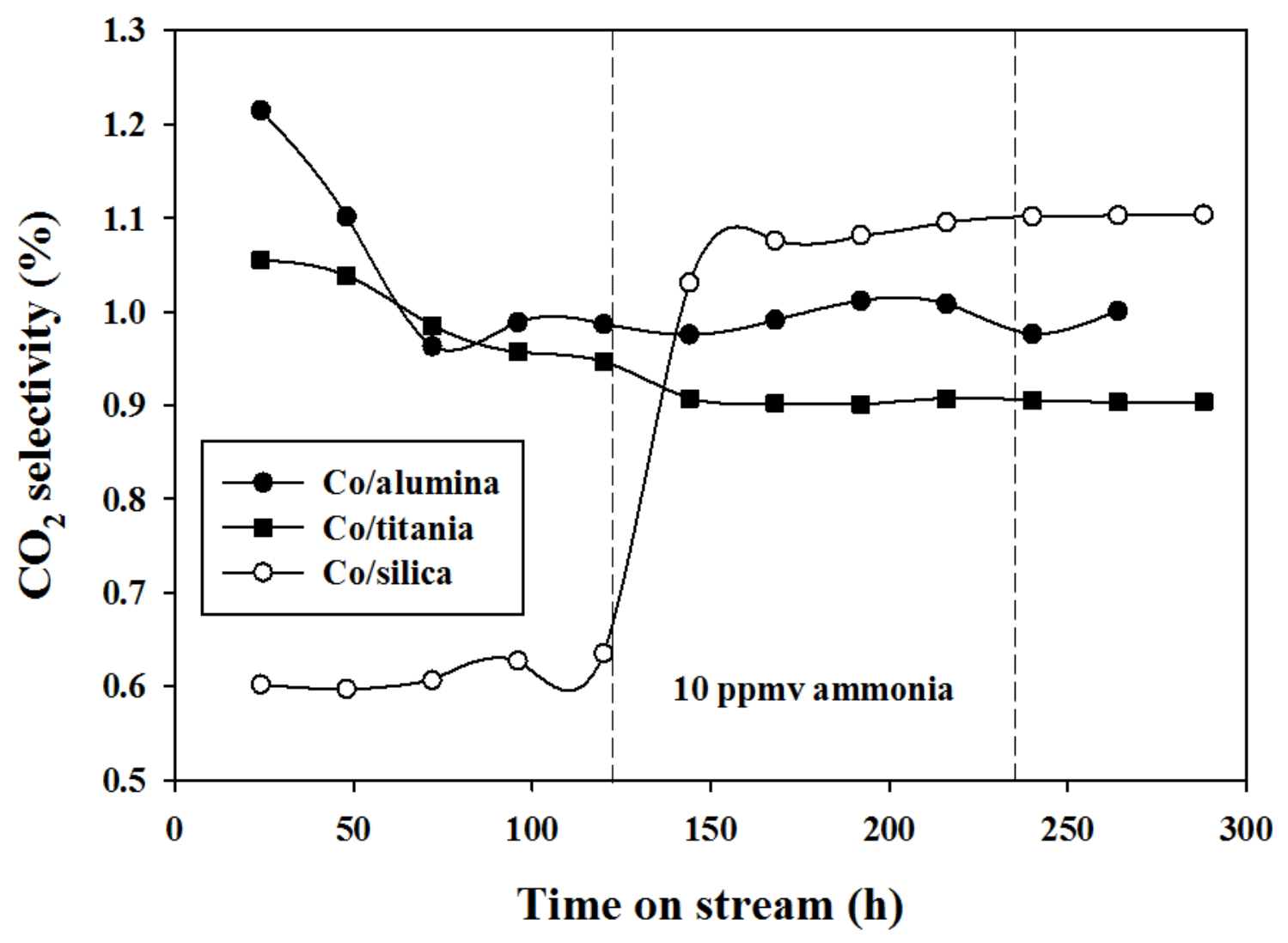

Figure 15 


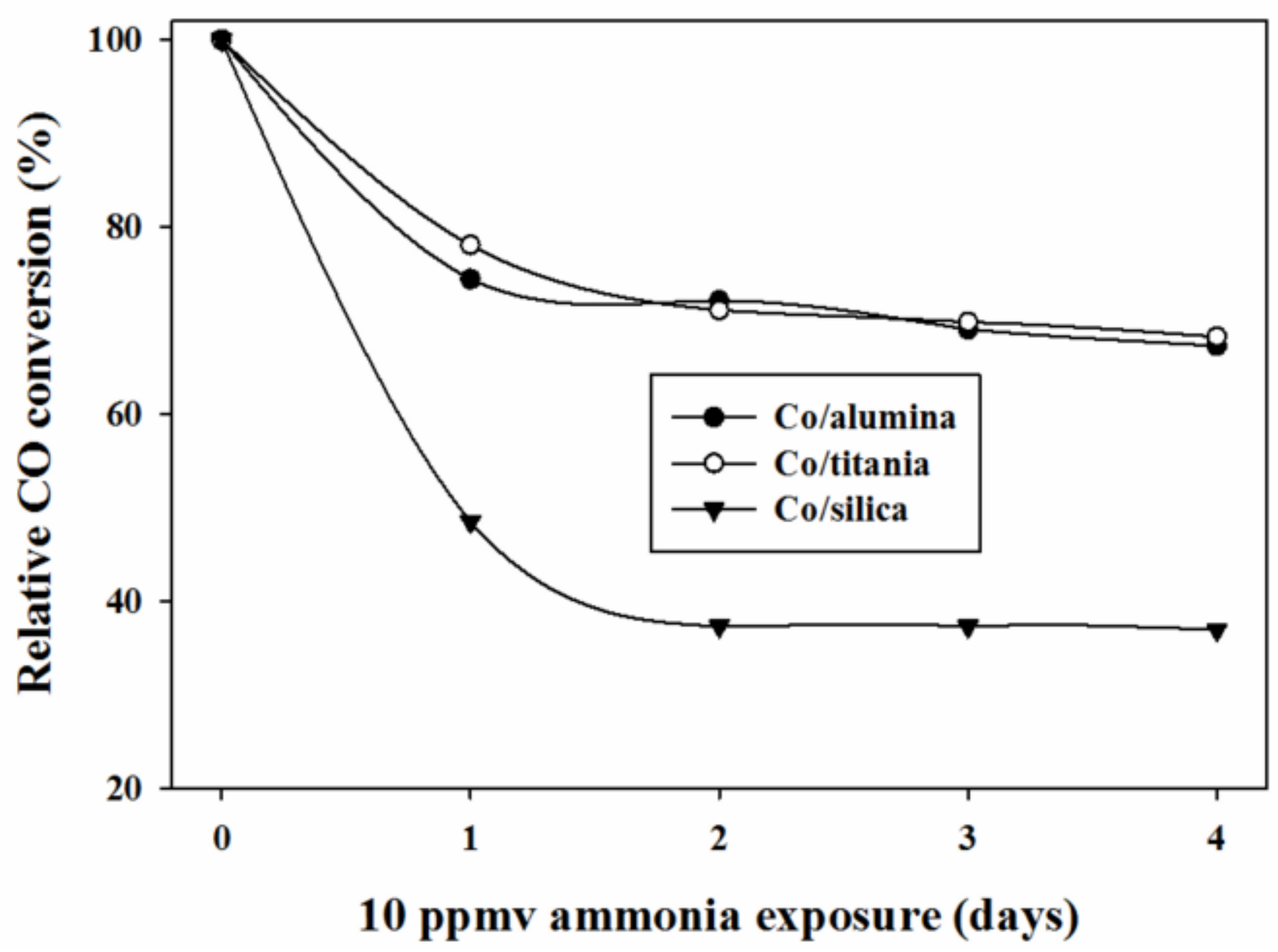

